\title{
1 Impact of dams and climate change on 2 suspended sediment flux to the Mekong 3
}

4

5 Gianbattista Bussi ${ }^{1,}{ }^{*}$, Stephen E. Darby², Paul G. Whitehead ${ }^{1,2}$, Li Jin ${ }^{3}$, Simon J. Dadson ${ }^{1}$, Hal 6 E. Voepel ${ }^{2}$, Grigorios Vasilopoulos ${ }^{4}$, Christopher R. Hackney ${ }^{5}$, Craig Hutton ${ }^{2}$, Tristan 7 Berchoux $^{6}$, Daniel R. Parsons ${ }^{4}$, Andrew Nicholas ${ }^{7}$

1 - School of Geography and the Environment, University of Oxford, South Parks Road, Oxford, OX1 3QY, UK

2-School of Geography and Environmental Sciences, University of Southampton, Avenue Campus, Highfield Road, Southampton SO17 1BJ, UK

3 - Geology Department, State University of New York College at Cortland, Cortland, NY 13045, US

4 - Energy and Environment Institute, University of Hull, Cottingham Road, Hull HU6 7RX, UK

5 - School of Geography, Politics and Sociology, Newcastle University, Newcastle upon Tyne, NE1 7RU UK

6 - TETIS, CIHEAM-IAMM, Univ Montpellier, AgroParisTech, CNRS, CIRAD, INRAE, Montpellier, France

7 - Department of Geography, University of Exeter, Exeter EX4 4RJ, UK

* Corresponding author 
The livelihoods of millions of people living in the world's deltas are deeply interconnected with the sediment dynamics of these deltas. In particular a sustainable supply of fluvial sediments from upstream is critical for ensuring the fertility of delta soils and for promoting sediment deposition that can offset rising sea levels. Yet, in many large river catchments this supply of sediment is being threatened by the planned construction of large dams. In this study, we apply the INCA hydrological and sediment model to the Mekong River catchment in South East Asia. The aim is to assess the impact of several large dams (both existing and planned) on the suspended sediment fluxes of the river. We force the INCA model with a climate model to assess the interplay of changing climate and sediment trapping caused by dam construction. The results show that historical sediment flux declines are mostly caused by dams built in PR China and that sediment trapping will increase in the future due to the construction of new dams in PDR Lao and Cambodia. If all dams that are currently planned for the next two decades are built, they will induce a decline of suspended sediment flux of 50\% (47-53\% $90 \%$ confidence interval $(90 \% \mathrm{Cl})$ ) compared to current levels ( $99 \mathrm{Mt} / \mathrm{y}$ at the delta apex), with potentially damaging consequences for local livelihoods and ecosystems. 


\section{Introduction}

The world's deltas are highly productive environments that support dense populations, but their lowlying land means that they are highly exposed to the threat of rising relative sea level (Ericson et al., 2006; Ibáñez et al., 2014; Syvitski, 2008). Indeed, there is a growing concern that accelerated rates of relative sea-level rise (Syvitski et al., 2009; Tessler et al., 2018) are now leading to an existential crisis for many of the world's deltas (Anthony et al., 2015; Day et al., 2016; Kondolf et al., 2018; Tessler et al., 2016, 2015). In deltas, rising relative sea-levels are driven primarily by a combination of eustatic sea-level rise and local ground subsidence, therefore a sustainable supply of fluvial sediment is critical to promote delta-plain sedimentation and hence prevent, or at least delay, deltas being 'drowned'.

A growing body of evidence indicates that the supply of fluvial sediment to many of the world's deltas is being disrupted by environmental change. A number of studies (Darby et al., 2016; Li et al., 2018; Walling, 2008; Walling and Fang, 2003) have shown that major declines in sediment loads to the coastal zone have occurred in recent decades, and a recent global projection (Dunn et al., 2019) highlights that this trend is likely to continue in the future. While natural climate variability can have an impact on sediment fluxes, there is broad consensus that both observed and projected reductions in sediment loads are a consequence of a global boom in dam construction for hydropower development (Grill et al., 2019; Vörösmarty et al., 2003; Zarfl et al., 2015). Importantly, the disrupted and fragmented rivers that feed many of the world's largest and most populous deltas (e.g., GangesBrahmaputra, Mekong, Nile) are often large and transboundary. In these systems, the major focus of dam construction may be located in nations upstream of the host delta itself, signifying a need to evaluate the system-wide trade-offs between the benefits of damming and the adverse impacts that may be propagated to downstream reaches and their deltas. In addition, these large rivers also face a range of additional stresses (including anthropogenic climate change) that manifest in variable intensities over the wide expanse of each river's catchment. In such circumstances it can be very challenging to attribute changes in the sediment loads reaching large deltas correctly, which can further inhibit effective trans-border cooperation and governance (Best, 2019).

One of the world's largest transboundary river systems is the Mekong. Until relatively recently, the Mekong had remained relatively unaffected by damming (Kummu et al., 2010). However, because of its considerable potential for hydropower generation (up to 268,000 GWh/yr; Schmitt et al., 2019), several hydropower dams have been constructed in recent decades. Others are under construction, nearing completion or planned, both on the main stem and on tributaries (Mekong River Commission, 2010, 2009). In its natural state the Mekong historically transported a high load of suspended sediments (160 Mt/yr; Milliman \& Meade, 1983) and associated nutrients, which together support the productive ecosystems of the lower Mekong floodplains (Chapman and Darby, 2016) and the world's largest freshwater fishery. The Mekong's dams are likely to reduce the sediment supply to the Mekong delta (Kondolf et al., 2014), with potentially damaging consequences on the agriculture, fishery and ecosystem of the delta (Baran and Myschowoda, 2009).

With large areas of the Mekong at risk of subsiding below mean sea level by 2100 (Minderhoud et al., 2019), continued fluvial sedimentation is key to offsetting the effects of land subsidence and sea level rise. Therefore, it is important to understand recent and future trends in fluvial suspended sediment flux and attribute changes to the correct cause. Some earlier previous studies (e.g., Darby et al., 2016; X. X. Lu \& Siew, 2006; Walling, 2008) suggest that, as of the mid-2000s, the effects of dams built on 
the Chinese part in the 1990s had not significantly affected sediment loads in the lower part of the basin, and specifically the flow of sediment to the delta. However, prior attempts to estimate the impact of planned dams on the sediment load to the delta have suggested that future sediment loads could be significantly affected: Kummu et al. (2010), for example, estimated a sediment load reduction of $51-69 \%$ if all planned dams are to be built, while Kondolf et al. (2014) found that the reduction could be as high as $96 \%$. However, previous empirical studies are now outdated, while the existing projections of future sediment loads: (i) focus exclusively on the impacts of damming; (ii) have employed damming databases that do not always identify all relevant infrastructure reliably, and; (iii) do not take into account other drivers, such as anthropogenic climate change.

Given the extreme importance of the Mekong delta for the livelihoods of the millions of people living there (Nguyen et al., 2019), and the enormous anthropogenic pressure that the Mekong River has been subject to in recent years, due to river damming and climate change, it is essential to assess accurately the impact of natural and anthropogenic stressors on the sediment flux of the Mekong River. In this paper we provide a comprehensive assessment of the potential impacts of future environmental change on future (to 2100) Suspended Sediment Flux (SSF) to the Mekong delta. We use a dynamic, semi-distributed, catchment model to identify how SSF has changed in the historical period (1980-2020) and will change in the future (2020-2100) throughout the Mekong's large, transboundary, basin, under the combined influence of dam construction and anthropogenic climate change. Importantly, we set the model up using the latest and most comprehensive database of damming available for the Mekong (provided by the Mekong River Commission). The focus of this paper is on the assessment of the influx of sediment to the apex of the delta, and therefore does not consider deltaic processes such as remobilisation by tides or erosion by sea storms.

This represents the first study in which the combined effects of climatic change and dam construction on the Mekong's sediment load have been considered. It represents a step towards understanding of the future dynamics of the Mekong River and its delta, both of which are controlled by the evolution of sediment supply. In addition, we seek to attribute projected declines in sediment flux to the countries within which dams are located in the Mekong's transnational catchment, affording an opportunity to focus potential future management interventions.

We show that recent past and future changes in SSF are driven primarily by the effects of damming. Specifically, we show that:

1. Historical declines (in the period 2000 to 2020) in sediment fluxes to the Mekong delta can be attributed dominantly to dams located in PR China (in 2020, 47\% (90\% Cl: [37\%, 54\%] of the total trapped sediment volume is attributed to dams in PR China, mainly due to new dams built in the 2000s and 2010s;

2. By 2040 the primary cause of the decline in the flow of suspended sediments to the Mekong delta will switch to the numerous dams located in PDR Lao (projected contribution to total trapped volume by 2040: $26 \%$ (90\% Cl: [24\%, 28\%])) and Cambodia (projected contribution to total trapped volume by $2040: 18 \%(90 \% \mathrm{Cl}$ : [16\%, 19\%])). 


\section{Methods}

\subsection{The Mekong River}

The Mekong River is one of the world's largest rivers, flowing from the Tibetan Plateau in China to the South China Sea, crossing PR China, PDR Lao, Myanmar, Thailand, Cambodia and Vietnam on its path. Its length is approximately $4,350 \mathrm{~km}$ and the catchment drainage area is approximately $800,000 \mathrm{~km}^{2}$ (Figure $1 \mathrm{~A}$ ). Figure $1 \mathrm{~B}$ shows the land use of the catchment, which is dominated by grassland and forest land in its upper part, and by agricultural land in the lower part. The fraction of urban land is relatively small $(1.5 \%)$ compared to the other land uses.
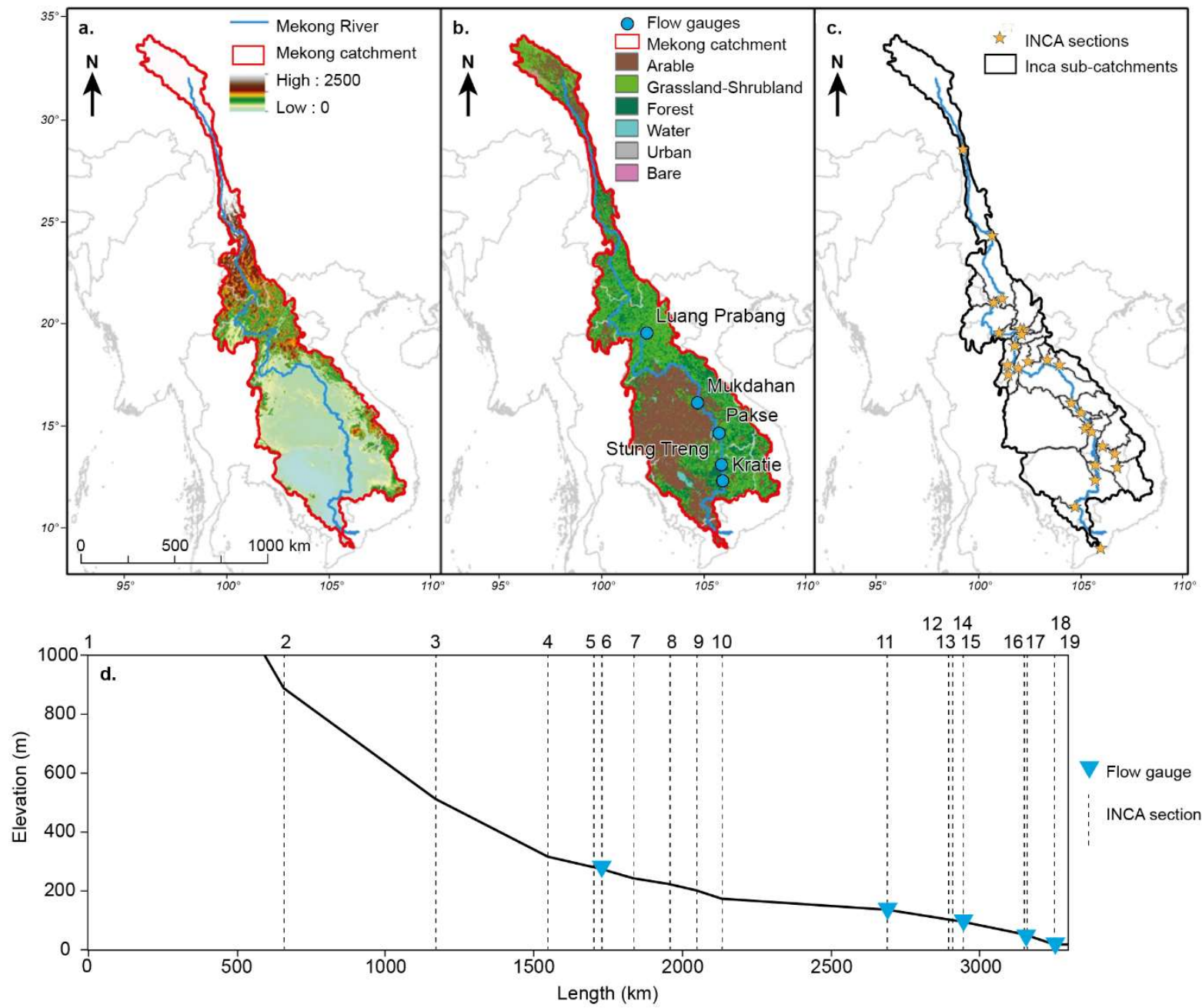

Figure 1. A) Mekong catchment extent and elevation. B) Mekong catchment land use and location of the flow gauges. C) INCA sub-catchment and river sections. D) Mekong river profile from section 1 (PR China-Thailand-PDR Lao border) to section 19 (river mouth), with INCA section and flow gauge locations.

The annual precipitation is around $1700 \mathrm{~mm}$, but shows strong seasonal variations, with strong predominance of the rainy southwest monsoon season (Kazama et al., 2007). The upper part of the catchment is a steep narrow valley primarily determined primarily by Himalayan orogeny (Gupta, 2009). The intermediate part of the catchment, in PDR Lao and Thailand, widens slightly, although it is still dominated by mountains. Its geology is formed by pre-Tertiary metamorphosed sedimentary 
with some clay and gravel. The lower basin is characterised by a flood plain filled with an alluvium of variable thickness (Gupta, 2009).

\subsection{The INCA model}

The INCA (INtegrated CAtchment) model is a semi-distributed, physically-based, hydrological and water quality model, that was initially developed during the 1990s (Whitehead et al., 1998) and which has been updated regularly ever since (Lázár et al., 2010; Lu et al., 2017, 2016; Nizzetto et al., 2016; Wade et al., 2002; Whitehead et al., 2016). In its various guises INCA has been applied to hundreds of catchments all over the world, including on large rivers such as the Ganges in India/Bangladesh (Whitehead et al., 2015) and the Mekong (Whitehead et al., 2019).

In this study, the INCA-P 1.4.11 model version was used (henceforth INCA-P; also used in Bussi et al., 2017; Bussi, Dadson, et al., 2016; Bussi, Whitehead, et al., 2016). The structure of the hydrological sub-model in INCA-P is described fully in Wade et al. (2002). In summary, the rainfall-runoff transformation is based on a simple mass balance, dividing hydrologically effective rainfall (i.e., the fraction of rainfall that contributes to flow) into direct runoff, soil water and groundwater, depending on the characteristics of the soil and the aquifer. The stream flow is then routed downstream by means of another mass balance and accounting for the characteristics of the river channel. The catchment under consideration is divided into a series of sub-catchments (for which the land phase parameters can be characterised individually based on land cover), so that these hydrological processes can be computed in a semi-distributed manner. The meteorological inputs required for the model are rainfall and temperature. These variables are used to compute the hydrologically effective rainfall and the soil moisture deficit, which are also required by INCA, by means of another hydrological model, PERSiST (Futter et al., 2014). PERSiST is a semi-distributed rainfall-runoff model specifically designed to compute input series for the INCA model. Other model inputs are topography, land use, point-source effluents (if any), channel width and slope.

The sediment transport component of the model is described in Jarritt and Lawrence (2006) and Lázár et al. (2010). A detailed description can also be found in Bussi et al. (2016). This sediment transport component of the INCA model can be divided into two sub-components: the land phase, which reproduces soil erosion and transport processes from the hillslope to the river network, and the channel phase, which simulates entrainment and storage processes within the river channel system. The sediment generation can be triggered by splash detachment, sheet erosion and rill erosion. Soil is eroded from a pool of parental material through the splash detachment and sheet erosion mechanisms and routed downstream to a pool of readily available sediment, which represents the sediment that is available to be transported to the river network. Sediment is classified into five textural classes: clay $(0-0.002 \mathrm{~mm})$, silt $(0.002-0.06 \mathrm{~mm})$, fine sand $(0.06-0.2 \mathrm{~mm})$, medium sand $(0.2-$ $0.6 \mathrm{~mm})$, and coarse sand $(0.6-2 \mathrm{~mm})$. The amount of sediment routed to the river network depends on the availability of sediment and the overland flow transport capacity. It should be noted that the model does not account for complete depletion of parent soils (because the parent material to be eroded is unlimited), but it does compute a balance between sediment availability and overland flow transport capacity in order to calculate the sediment mass to be transported downstream. The representation of the hillslope sediment cycle is therefore both transport-limited and supply-limited. The model accounts for the characteristics of the soil, the land use and the connectivity between slopes and channels. 
Once in the main river network, sediment is routed downstream as a function of the river transport capacity, which is computed separately for a range of texture classes using the Bagnold (1966) stream power equation. The transport capacity is used to split the material that enters the river reach into deposited and suspended, and to transfer the suspended part downstream. Depending on the size of the sediment and the transport capacity, the material can deposit into the riverbed and accumulate or be routed downstream. At the same time, again depending on the transport capacity and on sediment availability, deposited sediment can also be re-entrained. The balance between sediment availability and river flow transport capacity is also accounted for at the reach scale, thus providing a representation of the river sediment cycle which is both transport-limited and supply-limited, depending on a variety of factors such as climate, soils, land use, slope, etc. Background release of material (i.e., bank erosion) is also computed in a simplified way as a non-linear function of the river flow.

The INCA model does consider sediment deposition and re-entrainment within the river channel and allows for reproducing both transport-limited and supply-limited sediment transport. However, the INCA model is a catchment and river sediment model and does not consider long-term morphological changes to the river channel (other than sediment deposition or sediment depletion). This simplification is usually accepted in river sediment modelling because of the relatively short time period that is typically modelled, during which it is assumed that any geomorphological change will be negligible compared to other in-stream processes. The spatial scale is also relevant: in large-scale applications, local geomorphological changes might be negligible, while in small-scale application this might not be true. In the present study, we model more than 100 years over a large area. It can be assumed that no significant changes to the riverbed morphology are expected aside from deposition and remobilisation within this time frame and at this scale, especially because many previous studies point out that many sections of the river are bedrock-constrained (Carling et al., 2019; Kondolf et al., 2014; Meshkova and Carling, 2012; Nie et al., 2018; Van et al., 2012) and thus significant geomorphological changes are expected to take much more than just a century. This might not be true for the delta part of the river, however, as pointed out previously, this paper focuses on the inland part of the river and estimates the influx of sediment at the apex of the delta.

\subsection{Data, model set-up and model calibration}

Daily observed precipitation and temperature data were obtained from a network of several local stations. In particular, the Ministry of Water Resources and Meteorology of Cambodia provided 21 daily precipitation stations and 14 monthly temperature station, the KNMI's (Dutch met office) Climate Explorer platform another 14 precipitation and temperature stations within or adjacent to the Mekong delta (part of the Global Historical Climatology Network and managed by the corresponding national meteorological services), and the US National Climate Data Center 17 precipitation and temperature stations in PR China, 5 in PDR Lao and 24 in Thailand. These data were quality-controlled and processed to obtain daily precipitation and temperature time-series for the period from 1975 to 2016, covering the whole Mekong catchment. Land use data were obtained from the European Space Agency's GlobCover product (Bontemps et al., 2011), which maps the 2009 global land cover at $300 \mathrm{~m}$ resolution. The land use classes were aggregated into six classes: arable, grassland-shrubland, forest, urban and bare. Elevation maps were obtained from the Shuttle Radar Topography Mission (Farr et al., 2007) at a resolution of $90 \mathrm{~m}$ and were used to compute river reach lengths, sub-catchment extensions and reach slopes. Flow data used for model calibration and validation were obtained from 
hydrological records archived in the Mekong River Commission data portal. In this study, data from 1981 to 2005 were used, as in Darby et al. (2016). Daily sediment flux data for the same period were derived from Darby et al. (2016) (Figure 1B and Figure 1D).

Daily precipitation and temperature data from a climate model were employed to project changes in the future climate. The PRECIS Regional Circulation Model coupled to the GFDL-CM Global Circulation Model was employed in this study (Thuc et al., 2016; Whitehead et al., 2019). The Representative Concentration Pathways (RCPs) 4.5 and 8.5 were used to drive the climate model (Edenhofer et al., 2014; Janes et al., 2019). RCP 8.5 reproduces greenhouse gas emissions rising continuously throughout the 21st century and represents a relatively challenging situation. Emissions in RCP 4.5 peak around 2040, then decline. The results of the climate model were bias-corrected, applying a quantile mapping correction (Lafon et al., 2013) to reproduce the observed climate. These climate scenarios allow climate changes to be projected up to the year 2100.

A database of existing and planned dams was obtained from the Mekong River Commission. A total of 284 dams were identified, 30 of which are located on the main stem of the Mekong ( 7 of them are already in place), and the rest on tributaries (Figure 2). This database includes information on reservoir volume and year of construction (or planned year of construction). Around 130 dams exist at the moment, the rest are either under construction or planned. The trapping effect of the dams was reproduced by introducing short river reaches in the model structure just upstream of the dam locations. In these reaches, the model sediment transport capacity parameters were adjusted such that the long-term ratio between the sediment volume flowing out of the reach and the sediment volume flowing into the reach was equal to the trap efficiency of the reservoirs within the reach, the latter as computed according to Brune (1953). The method developed by Brune (1953) relates the sediment trap efficiency, i.e. the ratio of the sediment mass trapped by a dam to the total sediment mass transported by the river to the dam, to the ratio of the reservoir volume and the annual average inflow. This method also allows consideration of the behaviour of particles with different sizes in reservoirs. INCA is in fact set up to reproduce five textural classes: clay $(0-0.002 \mathrm{~mm})$, silt $(0.002-$ $0.06 \mathrm{~mm})$, fine sand $(0.06-0.2 \mathrm{~mm})$, medium sand $(0.2-0.6 \mathrm{~mm})$, and coarse sand $(0.6-2 \mathrm{~mm})$, and a maximum entrainable grain size is computed for each reach and each time-step based on the transport capacity equation. In the reaches where reservoirs are set up, this procedure mimics the trapping mechanisms of reservoirs: during low flows particles of all sizes settle, while during high flows fine particles are only partially trapped while coarse particles still mostly deposit. Changes in reservoir volume and hence trapping efficiency were modelled at a decadal disaggregation level, i.e., different trap efficiency values were computed for every decade from 1980 to 2100, based on the total reservoir volume at the end of each decade (in the case of historical decades) or the future damming scenario (in the case of future decades). 


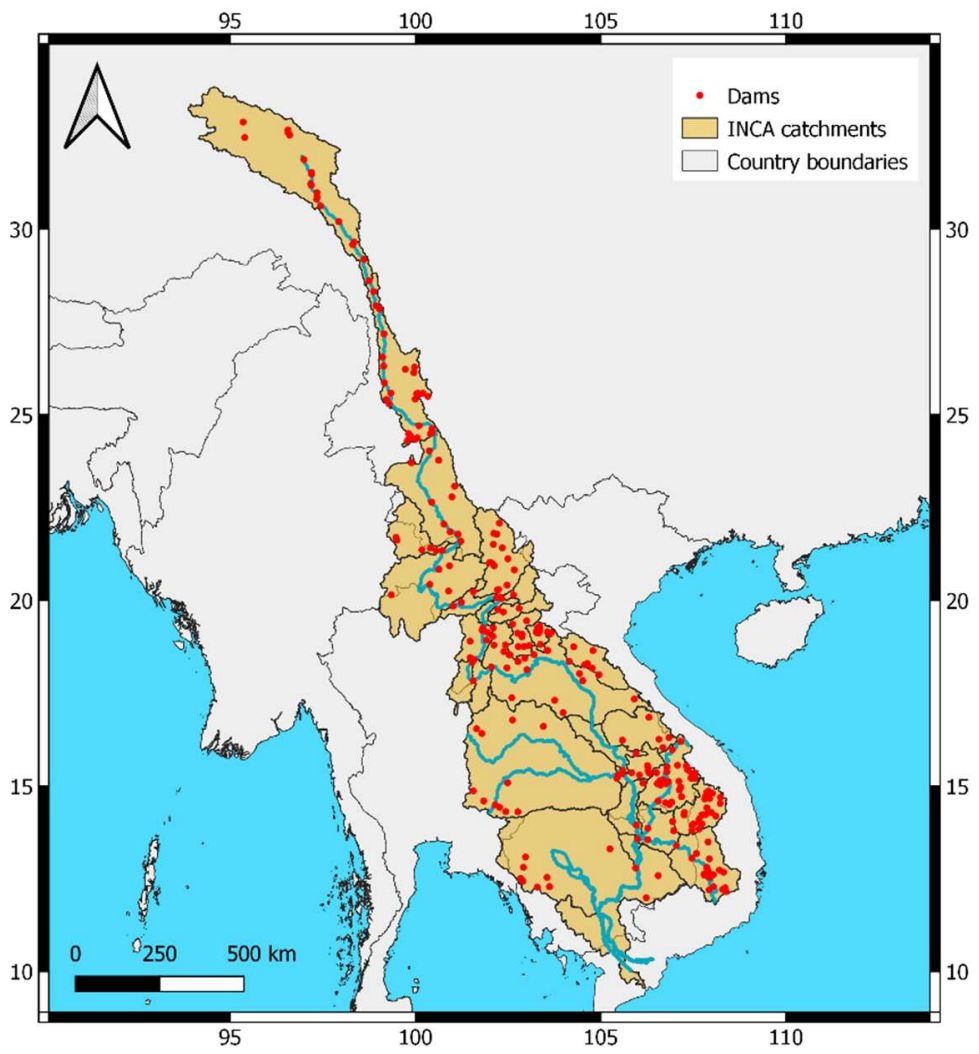

Figure 2. Spatial distribution of dams within the Mekong catchment.

Figure 1B shows the location of the flow gauges used for model calibration, namely: Luang Prabang (INCA reach 6), Mukdahan (reach 11), Pakse (reach 14), Stung Treng (reach 16) and Kratie (reach 17), with Figure $1 \mathrm{C}$ illustrating the extent of the sub-catchments employed here. Figure 1D shows a longitudinal profile of the river, extending from the source (reach 1 ) to the river mouth. The locations of the 19 main stem reach sections used in the INCA representation of the Mekong system and the flow gauges are also shown (the 11 other reach sections are set on tributaries). The coordinates and characteristics of the model reaches and their corresponding sub-catchments are reported in Table S6 in the Supplementary Material. The accumulated reservoir volume by INCA sub-catchment (Mm3) variation in time is shown in Table 1.

Table 1. Accumulated reservoir volume by INCA sub-catchment $\left(\mathrm{Mm}^{3}\right)$ and by decade.

\begin{tabular}{|c|c|c|c|c|c|c|c|c|c|c|}
\hline INCA ID & Name of the reach & 1950 & 1960 & 1970 & 1980 & 1990 & 2000 & 2010 & 2020 & 2030 \\
\hline 1 & Gushui & 0 & 0 & 0 & 0 & 0 & 0 & 0 & 4333 & 17490 \\
\hline 2 & Manwan & 0 & 0 & 335 & 494 & 2506 & 2506 & 23723 & 24762 & 24762 \\
\hline 3 & Ban Mau & 1490 & 1490 & 1490 & 1490 & 1490 & 3520 & 27223 & 27223 & 27800 \\
\hline 4 & Pak Beng & 0 & 0 & 0 & 0 & 0 & 0 & 4178 & 8825 & 8825 \\
\hline 5 & Luang Prabang & 0 & 0 & 0 & 0 & 0 & 0 & 4168 & 4168 & 5757 \\
\hline 6 & Luang Prabang Gauge & 0 & 0 & 0 & 0 & 0 & 0 & 1023 & 5521 & 5885 \\
\hline 7 & Xayabouri & 0 & 0 & 0 & 0 & 0 & 0 & 2026 & 2026 & 2026 \\
\hline 8 & Pak Lay & 0 & 0 & 0 & 0 & 0 & 0 & 473 & 2016 & 6227 \\
\hline 9 & Sanakham & 0 & 0 & 0 & 0 & 0 & 0 & 0 & 282 & 282 \\
\hline 10 & Santhong-Pakchom & 0 & 0 & 0 & 0 & 0 & 0 & 0 & 1097 & 1097 \\
\hline 11 & Mukdahan & 0 & 166 & 686 & 799 & 799 & 984 & 1282 & 3604 & 3604 \\
\hline 12 & Ban Kum & 0 & 0 & 0 & 0 & 0 & 0 & 0 & 2188 & 4298 \\
\hline 13 & Latsua & 0 & 0 & 0 & 0 & 225 & 225 & 225 & 2302 & 2302 \\
\hline 14 & Pakse & 0 & 0 & 0 & 0 & 0 & 0 & 0 & 0 & 0 \\
\hline 15 & Stung Treng & 0 & 0 & 0 & 0 & 0 & 0 & 0 & 0 & 669 \\
\hline 16 & Stung Treng Gauge & 0 & 0 & 0 & 0 & 0 & 0 & 1793 & 1793 & 1927 \\
\hline 17 & Sambor-Kratie & 0 & 0 & 0 & 0 & 0 & 0 & 0 & 3794 & 3794 \\
\hline
\end{tabular}




\begin{tabular}{|c|c|c|c|c|c|c|c|c|c|c|}
\hline 18 & Phnom Penh & 0 & 0 & 110 & 110 & 110 & 110 & 225 & 225 & 951 \\
\hline 19 & River mouth & 0 & 0 & 0 & 0 & 0 & 0 & 0 & 0 & 0 \\
\hline 20 & Nam Loi & 0 & 0 & 0 & 0 & 0 & 0 & 1755 & 3093 & 3823 \\
\hline 21 & Nam Suong & 0 & 0 & 0 & 0 & 0 & 0 & 0 & 4072 & 4072 \\
\hline 22 & Nam Khan & 0 & 0 & 0 & 0 & 0 & 0 & 4791 & 4791 & 4791 \\
\hline 23 & Nam Ngum & 0 & 0 & 4700 & 4700 & 4700 & 4700 & 8987 & 11251 & 11251 \\
\hline 24 & Nam Nhiep & 0 & 0 & 0 & 0 & 0 & 0 & 2984 & 3127 & 3127 \\
\hline 25 & Nam Cadinh & 0 & 0 & 0 & 0 & 0 & 0 & 8430 & 19099 & 19299 \\
\hline 26 & Se Bang Hieng & 0 & 0 & 0 & 0 & 0 & 0 & 540 & 2238 & 2238 \\
\hline 27 & Nam Mun & 0 & 4009 & 6451 & 7017 & 7017 & 7017 & 7017 & 7017 & 7017 \\
\hline 28 & Se Kong & 0 & 0 & 0 & 0 & 3530 & 3530 & 17663 & 25458 & 25956 \\
\hline 29 & Se San & 0 & 0 & 0 & 0 & 1073 & 2122 & 3332 & 3332 & 5785 \\
\hline 30 & Sre Pok & 0 & 0 & 0 & 0 & 0 & 933 & 1152 & 1152 & 3026 \\
\hline
\end{tabular}

267

268 Since INCA is not a fully distributed model, dams cannot be introduced at any location, and they must

269

270

271

272

273

274

275

276

277

278

279

280

281

282

283

284

285

286

287

288

289

290

291

292

293

294

295

296

297

coincide with the position of the downstream section of a reach. With the aim of achieving a reasonably simple model set-up while at the same time maximising the model performance, dams with a reservoir volume smaller than $100 \mathrm{Mm}^{3}$ (i.e., 124 dams in total) were not considered in this study. This is not a major limitation as these 124 small dams together account for less than $2 \%$ of the total reservoir storage volume in the Mekong cascade. The remaining 155 dams, which have a total reservoir storage volume of $208,000 \mathrm{Mm}^{3}$, were assigned to a corresponding model reach based on their geographical location. The location of the downstream sections of the model reaches was carefully selected in order to match the location of the largest reservoirs (see Figure 2). While the model reach sections of the main stem were specifically designed so that their corresponding subcatchments contained only one dam per reach, the tributary sub-catchments often contained more than one dam. In these cases, an equivalent reservoir volume was computed as the sum of all the reservoir volumes falling within the sub-catchment and this value was then used to compute a subcatchment trap efficiency by means of the Brune (1953) method. A discussion of this assumption is reported in the Supplementary Material.

The INCA model was calibrated by means of a Monte Carlo calibration procedure, according to the following steps. First, the most influential parameters were identified and a feasibility range for their values was estimated, based on previous applications of the model in other catchments. A list of the calibrated parameters is reported in Table 2, together with the corresponding feasibility range. A description of the parameters and their physical meaning is provided in Wade et al. (2002) and Bussi et al. (2016). Second, a large set of parameter values $(50,000)$ was generated randomly from uniform distributions within the defined feasibility ranges for each parameter. Third, the model was run with each parameter set and results were obtained. Fourth, all the results were analysed and the KlingGupta Efficiency index, or KGE (Gupta et al., 2009), was computed through comparison of observed and simulated daily flow and sediment flux time series, for locations where both flow and sediment records were available. Finally, a small number (15) of parameter sets was selected based on their performance and used to conduct the simulations described in this paper. The number of parameter sets to be used was chosen as a compromise between parameter set performance and computational burden.

Table 2. Calibrated model parameters and feasibility ranges.

\begin{tabular}{|c|c|c|c|}
\hline Parameter type & Parameter name & Minimum value & Maximum value \\
\hline catchment & Base Flow Index & 0.6 & 0.95 \\
\hline reach & Flow a & 0.02 & 0.1 \\
\hline reach & a8 (river transport capacity parameter) & 0.00001 & 0.001 \\
\hline
\end{tabular}




\begin{tabular}{|c|c|c|c|}
\hline reach & a9 (river transport capacity parameter) & 0.00001 & 0.001 \\
\hline catchment & groundwater zone time constant & 30 & 80 \\
\hline catchment & rainfall excess proportion & 0.05 & 0.2 \\
\hline catchment & threshold soil zone flow & 0.01 & 0.1 \\
\hline catchment & transport capacity non-linear coefficient & 0.2 & 0.8 \\
\hline catchment & transport capacity scaling factor & 0.2 & 0.7 \\
\hline land & direct runoff time constant & 1.5 & 2.5 \\
\hline land & flow erosion soil erodibility parameter (arable) & 0.6 & 2.4 \\
\hline land & flow erosion soil erodibility parameter (grassland) & 0.3 & 1.2 \\
\hline land & flow erosion soil erodibility parameter (forest) & 0.3 & 1.2 \\
\hline land & flow erosion soil erodibility parameter (wetland) & 0.1 & 0.5 \\
\hline land & flow erosion soil erodibility parameter (urban) & 0.1 & 0.5 \\
\hline land & flow erosion soil erodibility parameter (bare) & 5 & 20 \\
\hline land & soil reactive zone time constant & 5 & 9 \\
\hline land & splash detachment soil erodibility parameter (arable) & 0.9 & 3.5 \\
\hline land & splash detachment soil erodibility parameter (grassland) & 0.35 & 1.5 \\
\hline land & splash detachment soil erodibility parameter (forest) & 0.35 & 1.5 \\
\hline land & splash detachment soil erodibility parameter (wetland) & 0.07 & 0.3 \\
\hline land & splash detachment soil erodibility parameter (urban) & 0.07 & 0.3 \\
\hline land & splash detachment soil erodibility parameter (bare) & 8 & 35 \\
\hline
\end{tabular}

The INCA model was calibrated over the time period 1981-1989 (inclusive) and validated over the period 1990-2005 (inclusive). Comparisons of simulated and observed flows and sediment loads for all the five gauged sections investigated here, expressed in terms of monthly flow and monthly Suspended Sediment Flux (SSF), are shown in Figure 3 (the model calibration and validation was undertaken using daily flows and SSFs, but the data reported in Figure 3 are aggregated to monthly resolution for the purpose of aiding clarity of visualisation). The daily flow and suspended sediment flux KGEs obtained by the model are shown in Table 3.
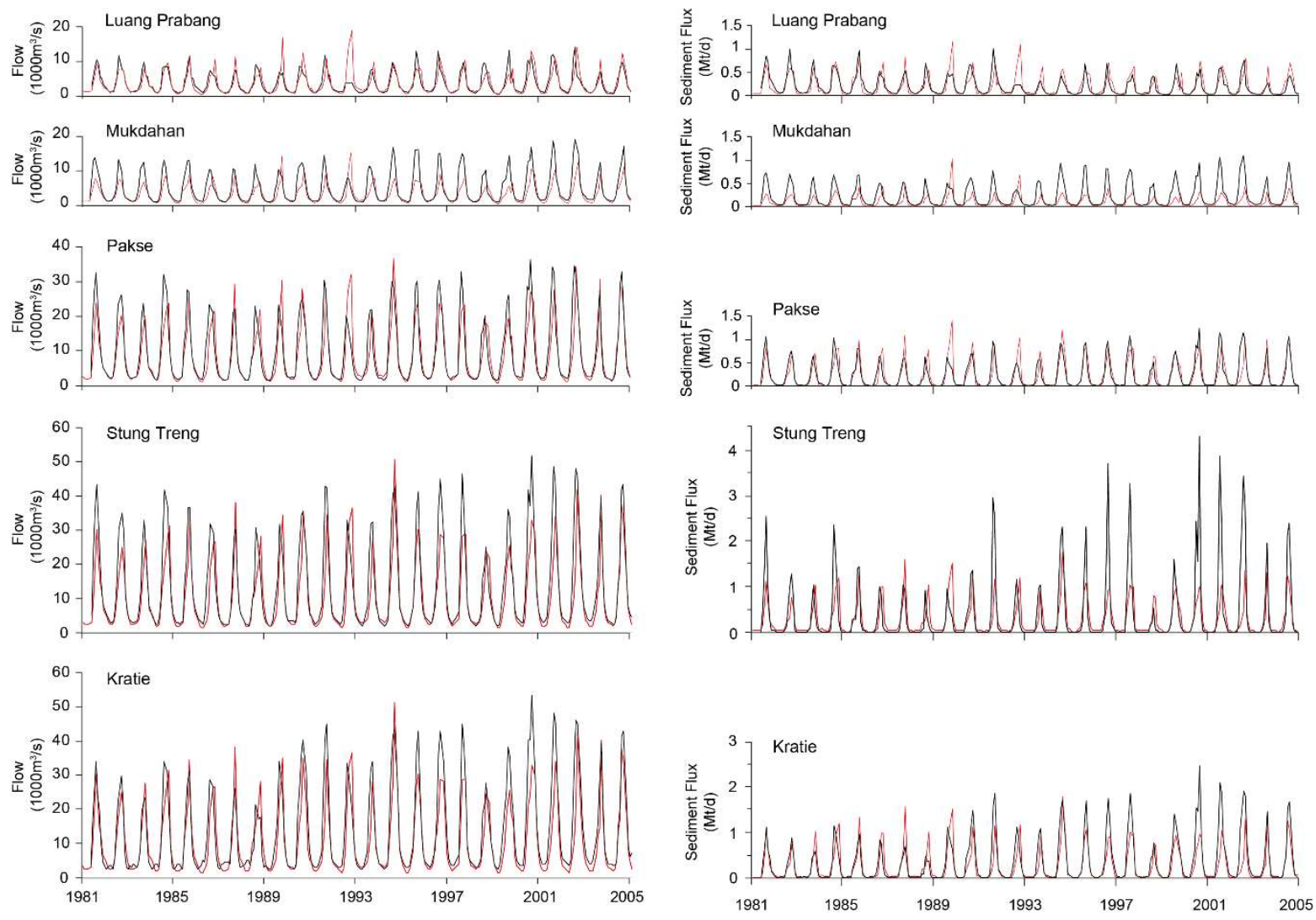
Figure 3. Calibration and validation results (monthly flow and monthly sediment flux) at five locations on the Mekong River (Luang Prabang, Mukdahan, Pakse, Stung Treng and Kratie).

Table 3. Kling-Gupta Efficiency (KGE) ranges obtained by the INCA model (ensemble of 15 parameter sets) computed on daily flow and monthly suspended sediment flux for the calibration (1980-1989) and validation (1990-2005) periods.

\begin{tabular}{|c|c|c|c|c|c|c|}
\hline Time period & Variable & Luang Prabang & Mukdahan & Pakse & Stung Treng & Kratie \\
\hline $1980-1989$ & Flow & $0.59-0.74$ & $0.41-0.54$ & $0.66-0.77$ & $0.61-0.71$ & $0.75-0.83$ \\
\hline $1980-1989$ & $\begin{array}{c}\text { Suspended } \\
\text { sediment flux }\end{array}$ & $0.45-0.71$ & $0.17-0.35$ & $0.38-0.73$ & $0.41-0.48$ & $0.37-0.7$ \\
\hline $1990-2005$ & Flow & $0.51-0.6$ & $0.31-0.44$ & $0.7-0.8$ & $0.62-0.72$ & $0.59-0.67$ \\
\hline $1990-2005$ & $\begin{array}{c}\text { Suspended } \\
\text { sediment flux }\end{array}$ & $0.13-0.58$ & $0.03-0.23$ & $0.59-0.78$ & $0.21-0.33$ & $0.45-0.62$ \\
\hline
\end{tabular}

\subsection{Model scenarios}

Here we investigated two climate change scenarios (corresponding to the RCP4.5 and RCP8.5 emissions scenarios, see for example Busico et al., 2019), and four damming scenarios: A) considering all dams built before 2010; B) considering all dams built or under construction before 2020; C) considering all dams planned for the near future (i.e., from 2021 to 2030); D) considering all dams planned for the far future (i.e., from 2031 onwards). In particular, all combinations of these climate and damming scenario were considered, as shown in Table 4.

Table 4. Scenarios considered in this study.

\begin{tabular}{|l|l|l|l|}
\hline \multicolumn{1}{|c|}{ Damming scenario } & \multicolumn{1}{|c|}{ Baseline climate } & Future climate (RCP4.5) & Future climate (RCP8.5) \\
\hline $\begin{array}{l}\text { A) considering all dams built before } \\
2010\end{array}$ & Baseline A & $R C P 4.5 \mathrm{~A}$ & $R C P 8.5 \mathrm{~A}$ \\
\hline $\begin{array}{l}\text { B) considering all dams built or under } \\
\text { construction before 2020 }\end{array}$ & Baseline B & $R C P 4.5 \mathrm{~B}$ & $R C P 8.5 \mathrm{~B}$ \\
\hline $\begin{array}{l}\text { C) considering all dams planned for } \\
\text { the near future (i.e., from 2021 to } \\
\text { 2030) }\end{array}$ & Baseline C & $R C P 4.5 \mathrm{C}$ & $R C P 8.5 \mathrm{C}$ \\
\hline $\begin{array}{l}\text { D) considering all dams planned for } \\
\text { the far future (i.e., from 2031 } \\
\text { onwards) }\end{array}$ & Baseline D & $R C P 4.5 \mathrm{D}$ & $R C P 8.5 \mathrm{D}$ \\
\hline
\end{tabular}

In all scenarios, the same ensemble of 15 model parameter sets was used (i.e., the 15 model parameter sets that gave the best KGE values for the daily SSF in the calibration stage), therefore obtaining a range of future sediment transport estimates rather than a single value.

\section{Results}

The results were analysed in terms of absolute value of SSF at different sections (the gauged sections were used as reference locations, i.e., Luang Prabang, Mukdahan, Pakse, Stung Treng and Kratie) and in terms of SSF variations compared to the baseline scenario (baseline climate, damming scenario A). Furthermore, the sediment decline caused by dams was attributed to different clusters of dams within each country in which they are located (including a "transboundary" cluster, for dams that lie on the border between two countries).

The model simulations estimate that the long-term Suspended Sediment Flux (SSF), as computed for the time period 1980-2009 (thus considering damming scenario A for the historical period), is 68.3 [60, 77.9] Mt/y, 34.3 [29.7, 39.5] Mt/y, 83.9 [76.3, 90.3] Mt/y, 98.7 [93.4, 103.2] Mt/y and 98.6 [93.4, 103.2] Mt/y for the stations at Luang Prabang, Mukdahan, Pakse, Stung Treng and Kratie, respectively (the confidence interval indicates the $90 \% \mathrm{Cl}$, based on the INCA model ensemble results). However, 
these values vary in time, mainly depending on climate variability and the construction of new dams, as shown in Table 5, where the SSFs of the same five sections are reported by decade.

Table 5. Suspended sediment flux (Mt/y) at five locations on the Mekong by decade. The values in the brackets show the $90 \%$ Cl.

\begin{tabular}{|c|c|c|c|c|c|}
\hline Decade & $\begin{array}{c}\text { Reach 06 (Luang } \\
\text { Prabang) }\end{array}$ & $\begin{array}{c}\text { Reach 11 } \\
\text { (Mukdahan) }\end{array}$ & Reach 14 (Pakse) & $\begin{array}{c}\text { Reach 16 (Stung } \\
\text { Treng) }\end{array}$ & Reach 17 (Kratie) \\
\hline $1980 \mathrm{~s}$ & $72.9[63.7,84.2]$ & $36.1[30.3,42.2]$ & $82.0[75.9,87.0]$ & $99.4[93.6,104.3]$ & $99.3[93.5,103.8]$ \\
\hline $1990 \mathrm{~s}$ & $66.8[58.8,76.6]$ & $34.5[30.3,40.0]$ & $84.3[75.6,92.3]$ & $96.7[90.3,105.5]$ & $96.6[90.3,105.3]$ \\
\hline $2000 \mathrm{~s}$ & $65.1[57.4,74.2]$ & $32.4[28.4,37.6]$ & $85.3[77.2,94.1]$ & $100.0[93.4,105.1]$ & $99.9[93.6,105.4]$ \\
\hline
\end{tabular}

The results of the INCA model driven by future climatic scenarios are shown in Figure 4 (please note that what appears to be a discontinuity in the SSF between the historical period and future period is in reality an effect of the decadal aggregation of the model results and the fact that between the historical and the future periods the total reservoir volume increased greatly). Figure 4 suggests that under RCP8.5 the increase in flow should occur earlier in time than under RCP4.5. For example, the model results indicate that the average flow is expected to reach $20,000 \mathrm{~m}^{3} / \mathrm{s}$ at Kratie by the $2050 \mathrm{~s}$ under the RCP8.5 scenario, but not until the 2070s-2080s under the RCP4.5 scenario.

Similar increases are indicated also in terms of SSF. However, the simulated impact of dams on sediment transport is greater than the impact of climate change. The dams built in the last decade (2010-2020, scenario B) are projected to reduce SSF to $44 \%, 30 \%, 86 \%, 88 \%$ and $71 \%$ of the SSF values simulated in the 2000s (scenario A) at Luang Prabang, Mukdahan, Pakse, Stung Treng and Kratie, respectively (with the projected future values of SSF being 30,13, 87, 107 and $87 \mathrm{Mt} / \mathrm{y}$ respectively, computed as the average of the 2030-2060 period under RCP4.5 emissions). The dams planned for the near future (2020-2030, scenario C) are projected to further lower the simulated SSFs to $40 \%, 11 \%$, $50 \%, 57 \%$ and $46 \%$ of their values in 2000 (with the projected future values of SSF being $27,4,42,57$ and $45 \mathrm{Mt} / \mathrm{y}$ respectively), while the dams planned for the far future (scenario D) reduce the SSF further still to $38 \%, 7 \%, 49 \%, 57 \%$ and $44 \%$ of the levels of the 2000 s (with the projected future values of SSF being $26,2,41,56$ and $45 \mathrm{Mt} / \mathrm{y}$ respectively). 
Flow
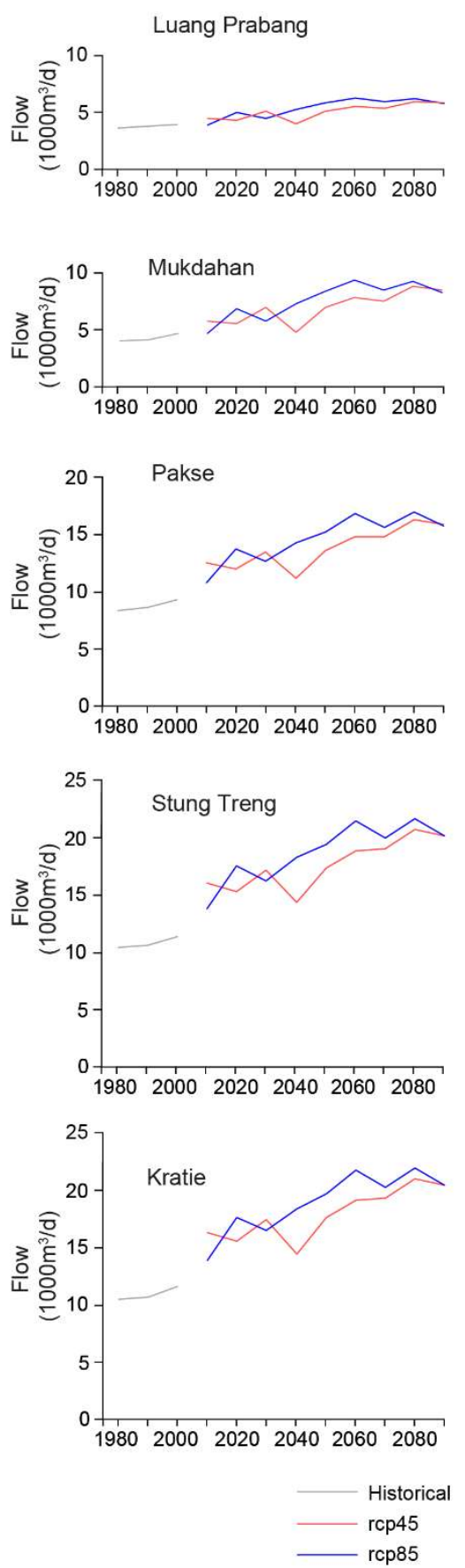

Sediment flux, RCP45
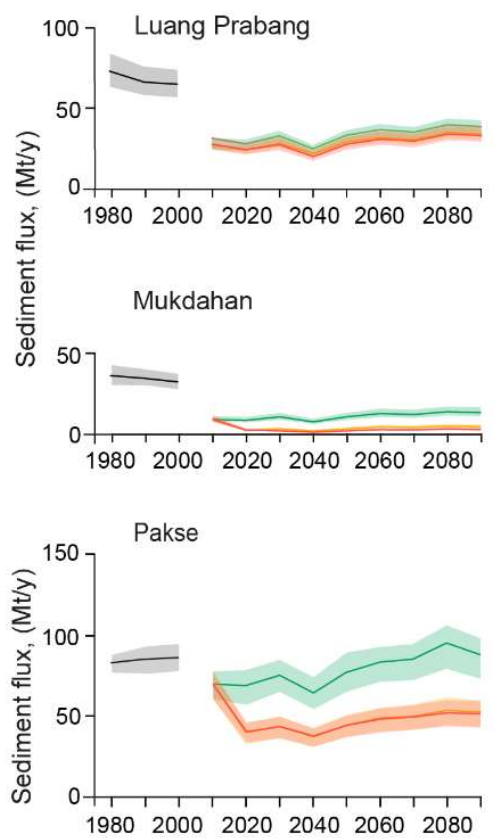

Stung Treng
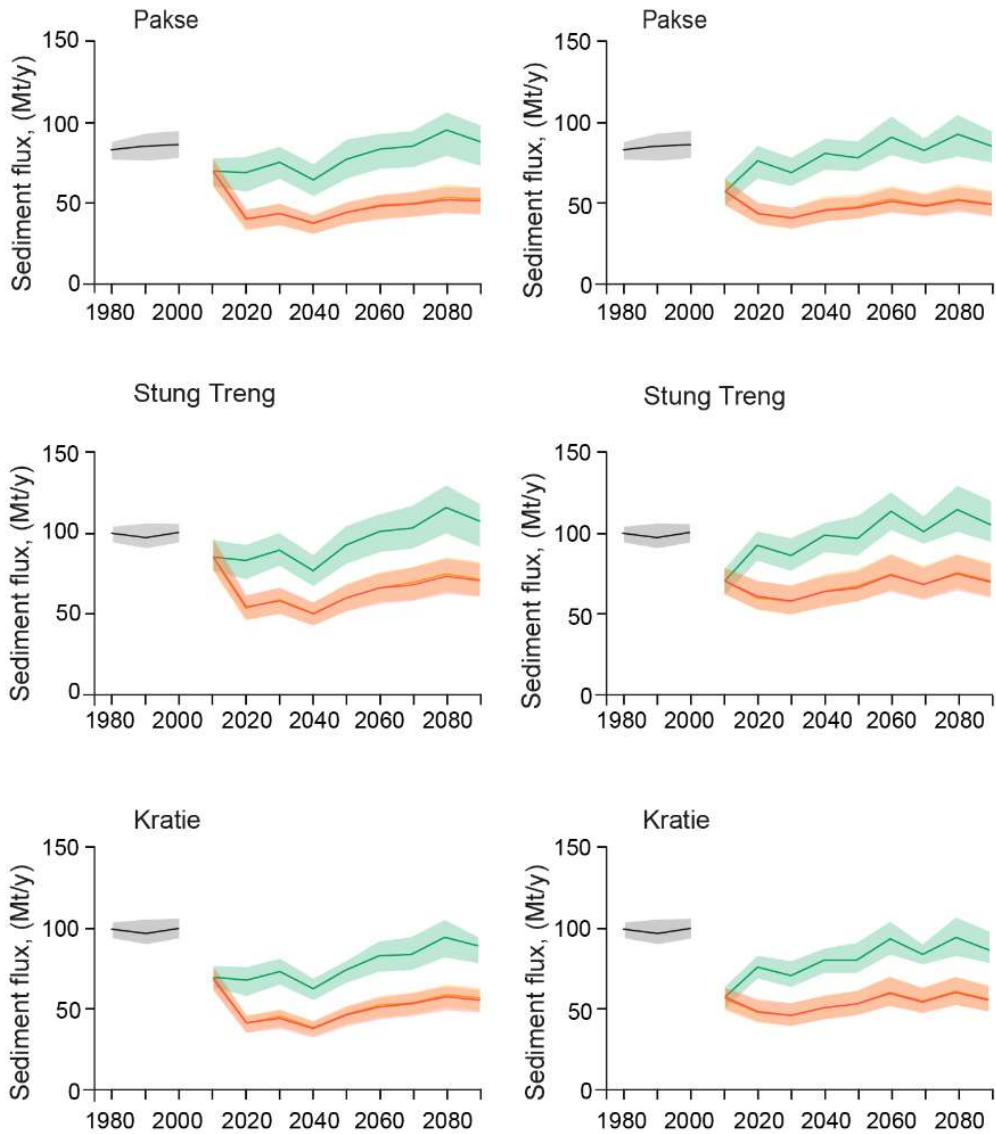

Stung Treng

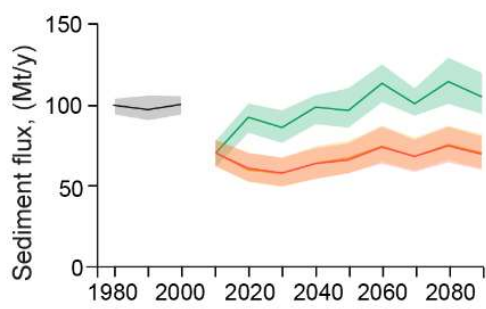

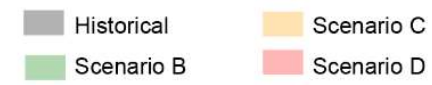

Figure 4. Flow and suspended sediment flux (SSF) projections driven by the GFDL climate model results under two RCP and three damming scenarios: B) considering all dams built before 2020 or under construction; C) considering all dams planned for the near future (i.e., up to 2030); D) considering all dams planned for the far future (i.e., after 2030). Scenario A (considering only dams built before 2010) is not projected into the future as is not feasible anymore. Note that the suspended sediment flux curves under scenarios $C$ and D partially overlap. The shaded areas represent the $90 \% \mathrm{Cl}$.

Figure 5 provides a visualisation of the variation of the annual trapped sediment mass, and the cumulative, increase in sediment mass trapped behind the dams, for the period from 1980 to 2100, as projected by INCA under the RCP8.5 scenario for all constructed and planned dams (i.e., Scenario D from Figure 4). In this diagram the results are grouped to show the accumulated impact of trapping behind dams located in each of the Mekong's countries. Note that a total of 7 dams are located on 
the border between two countries (PDR Lao-Cambodia or PDR Lao-Thailand) and these are shown in 371 the "Transboundary" category (lower right panel in Figure 5). For reference, Figure 6 shows the 372 variation in time of the total reservoir storage per country.
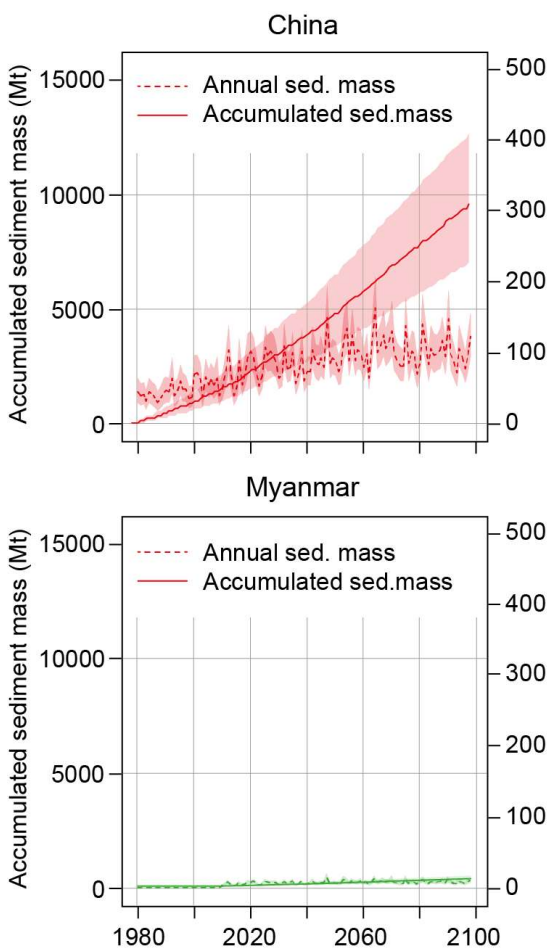

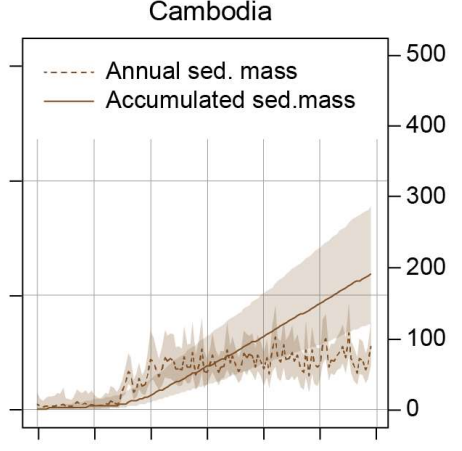

Thailand

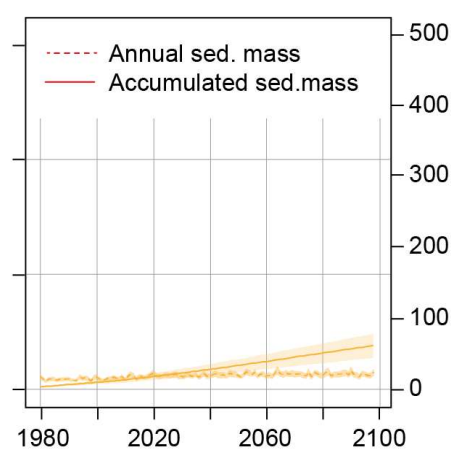

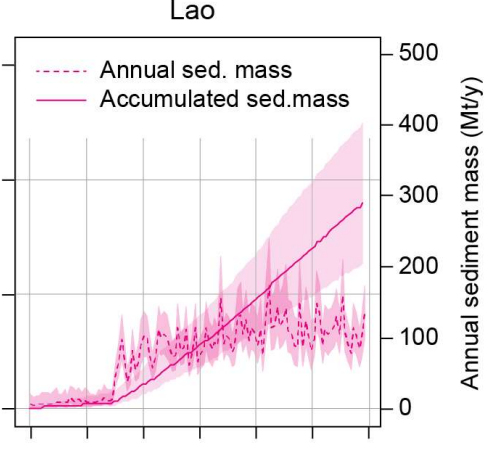

Transboundary

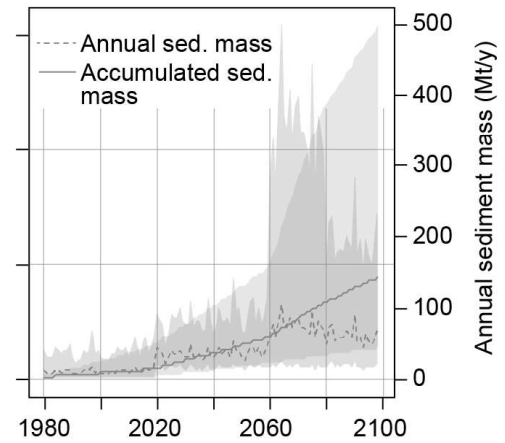

Figure 5. Annual and accumulated sediment mass trapped in reservoirs starting from 1980, grouped by country, under RCP8.5 and assuming that all planned dams are built (scenario D). Reservoirs built on the border of two countries are grouped in the "Transboundary" category. The shaded areas represent the $90 \% \mathrm{Cl}$.
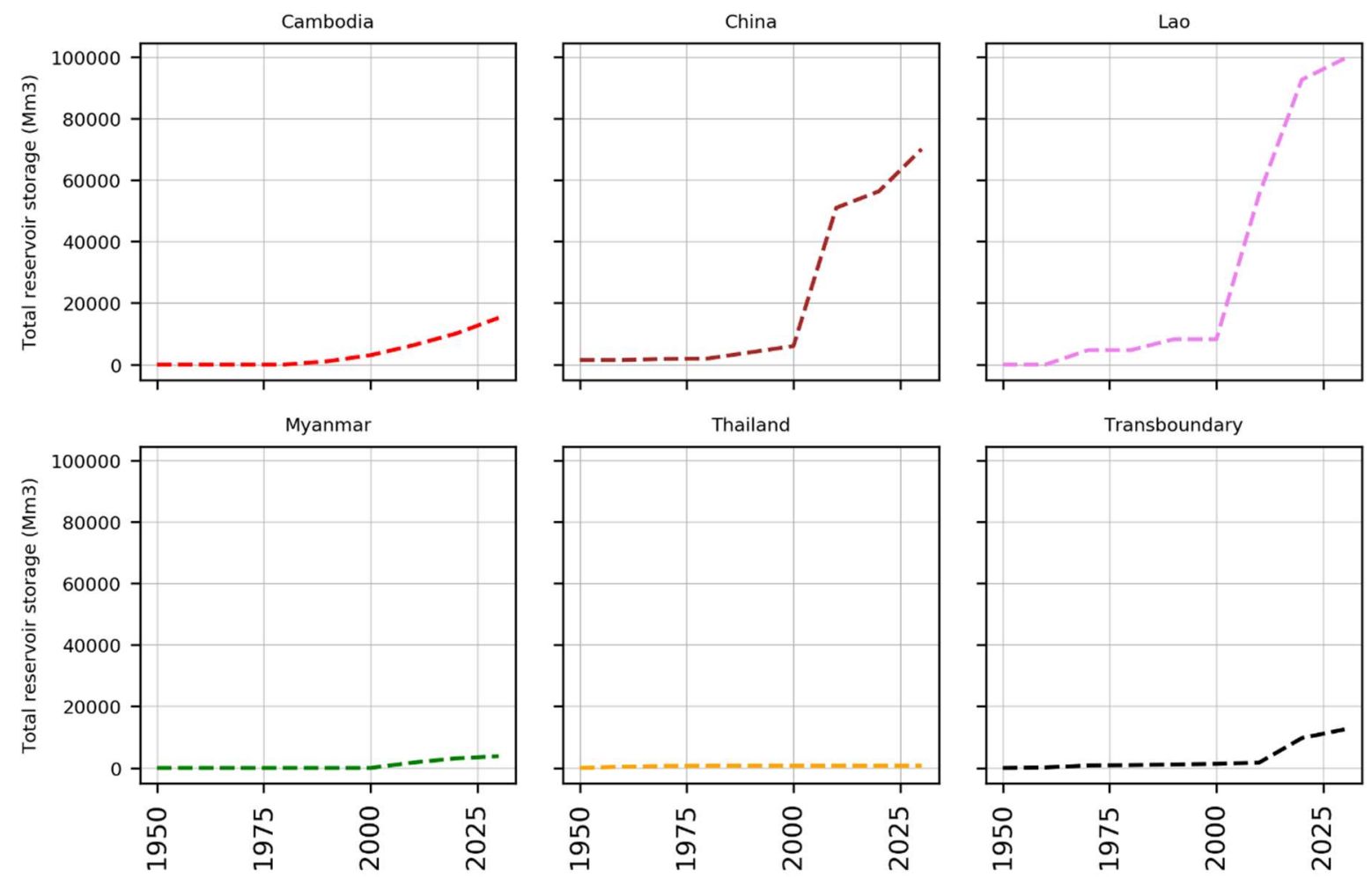


\section{Discussion}

Although previous studies (Kondolf et al., 2014; Kummu et al., 2010) have sought to quantify the impact of damming on the suspended sediment load of the Mekong River, to date none have considered the combined impacts of damming and human-induced changes in climate. In this study we demonstrate that these two drivers of change have opposing impacts on the Mekong's future suspended sediment load. However, although anthropogenic climate change is expected to increase river flows and suspended sediment fluxes to the delta, the climate-driven uplift in future sediment flux is not large enough to fully compensate for sediment retention by dams and reservoirs.

The climatic projections used in this study indicate that mean annual average temperature over the Mekong catchment is expected to increase by between 2 (RCP4.5) and 3 (RCP8.5) degrees Celsius by the 2060s. Precipitation is also expected to increase, especially during the rainy season, by $10 \%$ in 2030-2060 and by $26 \%$ in 2060-2090 under the RCP4.5 scenario. The RCP8.5 projections predict a similar, but slightly larger, increase of precipitation. The combined effect of these changes on INCA simulated flows is an increase in the mean annual river flow, of up to $70 \%$ compared to current values at Kratie (which is located close to the apex of the delta), as shown in Figure 4. Climate change is therefore expected to increase flows towards the delta, consistent with Wang et al. (2017), who also projected a sharp increase in flood magnitude in the Mekong.

Regarding future fluxes of sediment, our study suggests that the mean annual Suspended Sediment Flux (SSF) to the Mekong delta (as computed at Kratie), has recently (1980-2009) been as high as 99 (93-103) Mt/y. This INCA-derived estimate of the near-contemporary SSF is broadly consistent with previous estimates derived from measurements, such as those of Darby et al. (2016) (87.4 $\pm 28.7 \mathrm{Mt} / \mathrm{y}$, computed also at Kratie, for the time period 1981-2005); Kummu \& Varis (2007) (81 Mt/y at Kratie, over the time period 1995-2000) and X. Lu et al. (2014) (113 Mt/y at Pakse, $400 \mathrm{~km}$ upstream of Kratie, over the time period 1993-2000).

What our study highlights, however, is that rapid changes within the Mekong catchment have in effect rendered these prior empirical estimates of SSF redundant. In particular, the rapid increase in damming intensity in the first and second decades of the $21^{\text {st }}$ century (the total storage of the Mekong catchment dams was 22,200 $\mathrm{Mm}^{3}$ in 2000, 46,300 $\mathrm{Mm}^{3}$ in 2010 and will reach 147,000 $\mathrm{Mm}^{3}$ in 2020) are reflected in a major transition in the Mekong's SSF in the same period. Specifically, in the upper part of the catchment (Luang Prabang), SSF was $68[60,78] \mathrm{Mt} / \mathrm{year}$ for the period 1980-2009, but is projected to decrease to 26 [23, 30] Mt/year for the 2010-2019 decade and 24 [21, 28] Mt/year for the 2020-2029 decade, under the RCP4.5 scenario. In the long term (2070-2099), SSF at Luang Prabang is expected to recover slightly, up to $38[33,43] \mathrm{Mt} / \mathrm{yr}$. At Kratie, SSF is projected to decrease from 99 $[93,103] \mathrm{Mt} / \mathrm{y}$ during the 1980-2009 period to $46[40,51] \mathrm{Mt} / \mathrm{yr}$ for the 2010-2019 decade and 43 [37, 47] Mt/year for 2020-2029, under the RCP4.5 scenario (decreases of $53 \%$ and $57 \%$, respectively, since 1980-2009).

In the long term (2070-2099), SSF at Kratie is, as the effects of anthropogenic climate change become relatively more pronounced as the century progresses, expected to recover slightly to $62[56,68]$ $\mathrm{Mt} / \mathrm{year}$, i.e. around two thirds of what it was in 1980-2009. Nevertheless, the scale of reduction in sediment load is still substantial, reinforcing recent work that highlights how the opportunity to 
manage the Mekong's dam portfolio to limit the adverse potential for sediment trapping is already severely constrained (Schmitt et al., 2019).

As noted above, our findings also highlight that, according to the climate scenarios, SSF should recover in the longer term, although not enough to attain the levels of the recent (1980-2009) period. At Luang Prabang, SSF should increase by 26\% (compared to 2010-2029 levels) by 2070-2099 under the RCP4.5 scenario and by $38 \%$ under the RCP8.5 scenario. At Kratie, these figures are $27 \%$ and $31 \%$, respectively. Figure 4 summarises this situation: if no more dams are built (scenario B; unlikely), SSFs should be able to recover to past levels towards the end of the century in the downstream part of the catchment (Pakse, Stung Treng, Kratie), but should not be able to recover in the upstream part (Luang Prabang, Mukdahan). However, if all planned dams are built, the lower Mekong catchment will also experience a long-term decline in sediment fluxes, with significant implications on livelihoods in the delta.

It must be highlighted that for a comprehensive analysis of the delta dynamics, all the component of the delta sediment balance should be considered, including inputs from upstream, wave and tide erosion, subsidence, etc. This paper focuses on a single component of this balance, the inflow from the river. The results of the present study certainly contribute to the understanding of the whole sediment balance in the delta and are fundamental for the quantification of its sediment inputs. However, other processes occur in the delta that might play a relevant role and were not within the scope of the present study.

\section{Conclusion}

In this study, the impact of sediment trapping caused by damming and of climate change on the sediment fluxes of the Mekong River was quantified. This paper provides the first joint dammingclimate change impact assessment for the Mekong River, filling the gaps of previous studies. The results suggest that the rapid increase in damming intensity in the first and second decades of the $21^{\text {st }}$ century will have a major effect on the supply of sediment transmitted through the Mekong River.. Specifically, the suspended sediment flux in the lower Mekong is expected to change from $99[93,103]$ $\mathrm{Mt} / \mathrm{y}$ to 43 [37, 47] Mt/year by 2020-2029 (57\% decrease). Our simulations highlight that these declines will not be recovered, despite a projected increase in runoff and sediment transport towards the end of the century, as a consequence of climate change.

The major declines in suspended sediment loads and associated problems that our INCA projections indicate have already started to manifest in the last two decades. Our simulations highlight that these declines will not be recovered despite a projected increase in runoff and sediment transport by 2100 caused by climate change. Thus, they present a major challenge for sustainable development across the Mekong basin. For example in the upper reaches of the Lower Mekong Basin (at stations such as Luang Prabang and Pakse), declining sediment loads are likely to result in in-channel erosion, with potential adverse impacts on riparian communities and infrastructure, as sediment starved waters released from dams remobilise sediments stored in the Mekong floodplains (Kondolf, 1997). Further downstream, the dramatic decline of SSF delivered from the Lower Mekong (Kratie) presents an existential threat to the Mekong delta. Fluvial sediment deposition on the delta plains, is the only mechanism capable to offset the effects of relative sea-level rise and is very likely to decline. Moreover, a deficit in sediment deposition also threatens the sustainability of agricultural systems and local livelihoods in the delta. 
Our results highlight how these local impacts arise from the effects of dams located in distinctive upstream jurisdictions in this transnational basin. Our results show that by 2020 47\% of the total retained sediment mass was trapped by dams built in PR China, $13 \%$ by dams in Cambodia and $21 \%$ by dams in PDR Lao, however these figures will change to $35 \%, 19 \%$ and $27 \%$, respectively by 2050 , if all planned dams are built. Transboundary dams, mostly built on the PDR Lao-Cambodia and PDR Lao - Thailand borders, are projected to trap $10 \%$ of the total trapped sediment by 2050. It is clear that efforts to mitigate severe reductions in SSF will require effective cooperation and governance across borders.

\section{Acknowledgments}

The research reported here was supported by awards BB/P022693/1 and NE/S002847/1 from the Biotechnology and Biological Sciences Research Council and the Natural Environment Research Council, respectively.

\section{References}

Anthony, E.J., Brunier, G., Besset, M., Goichot, M., Dussouillez, P., Nguyen, V.L., 2015. Linking rapid erosion of the Mekong River delta to human activities. Sci. Rep. 5, 14745. https://doi.org/10.1038/srep14745

Bagnold, R.A., 1966. An approach to the sediment transport problem from general physics. Geological Survey Professional Paper 422-I. U.S. Government Printing Office, Washington, DC.

Baran, E., Myschowoda, C., 2009. Dams and fisheries in the Mekong Basin. Aquat. Ecosyst. Health Manag. 12, 227-234. https://doi.org/10.1080/14634980903149902

Best, J., 2019. Anthropogenic stresses on the world's big rivers. Nat. Geosci. 12, 7-21. https://doi.org/10.1038/s41561-018-0262-x

Bontemps, S., Defourny, P., Bogaert, E.V., Arino, O., Kalogirou, V., Perez, J.R., 2011. GLOBCOVER 2009-Products description and validation report.

Brune, G.M., 1953. Trap efficiency of reservoirs. Trans. AGU 34, 407-418.

Busico, G., Giuditta, E., Kazakis, N., Colombani, N., 2019. A Hybrid GIS and AHP Approach for Modelling Actual and Future Forest Fire Risk Under Climate Change Accounting Water Resources Attenuation Role. Sustainability 11, 7166. https://doi.org/10.3390/su11247166

Bussi, G., Dadson, S.J., Prudhomme, C., Whitehead, P.G., Prudhomme, C., 2016a. Modelling the future impacts of climate and land-use change on suspended sediment transport in the River Thames (UK). J. Hydrol. 542, 357-372. https://doi.org/10.1016/j.jhydrol.2016.09.010

Bussi, G., Janes, V., Whitehead, P.G., Dadson, S.J., Holman, I.P., 2017. Dynamic response of land use and river nutrient concentration to long-term climatic changes. Sci. Total Environ. 590-591, 818-831. https://doi.org/10.1016/j.scitotenv.2017.03.069 
Bussi, G., Whitehead, P.G., Bowes, M.J., Read, D.S., Prudhomme, C., Dadson, S.J., 2016b. Impacts of climate change, land-use change and phosphorus reduction on phytoplankton in the River Thames (UK). Sci. Total Environ. 572, 1507-1519. https://doi.org/10.1016/j.scitotenv.2016.02.109

Carling, P.A., Huang, H.Q., Su, T., Hornby, D., 2019. Flow structure in large bedrockchannels: The example of macroturbulent rapids, lower Mekong River, Southeast Asia. Earth Surf. Process. Landforms 44, 843-860. https://doi.org/10.1002/esp.4537

Chapman, A., Darby, S., 2016. Evaluating sustainable adaptation strategies for vulnerable mega-deltas using system dynamics modelling: Rice agriculture in the Mekong Delta's An Giang Province, Vietnam. Sci. Total Environ. 559, 326-338. https://doi.org/10.1016/j.scitotenv.2016.02.162

Darby, S.E., Hackney, C.R., Leyland, J., Kummu, M., Lauri, H., Parsons, D.R., Best, J.L., Nicholas, A.P., Aalto, R., 2016. Fluvial sediment supply to a mega-delta reduced by shifting tropical-cyclone activity. Nature 539, 276-279. https://doi.org/10.1038/nature19809

Day, J.W., Agboola, J., Chen, Z., D’Elia, C., Forbes, D.L., Giosan, L., Kemp, P., Kuenzer, C., Lane, R.R., Ramachandran, R., Syvitski, J., Yañez-Arancibia, A., 2016. Approaches to defining deltaic sustainability in the 21 st century. Estuar. Coast. Shelf Sci. 183, 275-291. https://doi.org/10.1016/j.ecss.2016.06.018

Dunn, F.E., Darby, S.E., Nicholls, R.J., Cohen, S., Zarfl, C., Fekete, B.M., 2019. Projections of declining fluvial sediment delivery to major deltas worldwide in response to climate change and anthropogenic stress. Environ. Res. Lett. 14, 084034. https://doi.org/10.1088/1748-9326/ab304e

Edenhofer, O., Pichs-Madruga, R., Sokona, Y., Farahani, E., Kadner, S., Seyboth, K., Adler, A., Baum, I., Brunner, S., Eickemeier, P., Kriemann, B., 2014. Summary for policymakers climate change 2014, mitigation of climate change. IPCC 2014, Climate Change 2014: Contribution of Working Group III to the Fifth Assessment Report of the Intergovernmental Panel on Climate Change.

Ericson, J.P., Vorosmarty, C.J., Dingman, S.L., Ward, L.G., Meybeck, M., 2006. Effective sealevel rise and deltas: Causes of change and human dimension implications. Glob. Planet. Change 50, 63-82. https://doi.org/10.1016/j.gloplacha.2005.07.004

Farr, T.G., Rosen, P.A., Caro, E., Crippen, R., Duren, R., Hensley, S., Kobrick, M., Paller, M., Rodriguez, E., Roth, L., Seal, D., Shaffer, S., Shimada, J., Umland, J., Werner, M., Oskin, M., Burbank, D., Alsdorf, D., 2007. The Shuttle Radar Topography Mission. Rev. Geophys. 45, RG2004. https://doi.org/10.1029/2005RG000183

Futter, M.N., Erlandsson, M.A., Butterfield, D., Whitehead, P.G., Oni, S.K., Wade, A.J., 2014. PERSiST: a flexible rainfall-runoff modelling toolkit for use with the INCA family of models. Hydrol. Earth Syst. Sci. 18, 855-873. https://doi.org/10.5194/hess-18-855-2014 
Grill, G., Lehner, B., Thieme, M., Geenen, B., Tickner, D., Antonelli, F., Babu, S., Borrelli, P., Cheng, L., Crochetiere, H., Ehalt Macedo, H., Filgueiras, R., Goichot, M., Higgins, J., Hogan, Z., Lip, B., McClain, M.E., Meng, J., Mulligan, M., Nilsson, C., Olden, J.D., Opperman, J.J., Petry, P., Reidy Liermann, C., Sáenz, L., Salinas-Rodríguez, S., Schelle, P., Schmitt, R.J.P., Snider, J., Tan, F., Tockner, K., Valdujo, P.H., van Soesbergen, A., Zarfl, C., 2019. Mapping the world's free-flowing rivers. Nature 569, 215-221. https://doi.org/10.1038/s41586-019-1111-9

Gupta, A., 2009. Geology and Landforms of the Mekong Basin, in: The Mekong. Elsevier, pp. 29-51. https://doi.org/10.1016/B978-0-12-374026-7.00003-6

Gupta, H.V., Kling, H., Yilmaz, K.K., Martinez, G.F., 2009. Decomposition of the mean squared error and NSE performance criteria: Implications for improving hydrological modelling. J. Hydrol. 377, 80-91. https://doi.org/10.1016/j.jhydrol.2009.08.003

Ibáñez, C., Day, J.W., Reyes, E., 2014. The response of deltas to sea-level rise: Natural mechanisms and management options to adapt to high-end scenarios. Ecol. Eng. 65, 122130. https://doi.org/10.1016/j.ecoleng.2013.08.002

Janes, T., McGrath, F., Macadam, I., Jones, R., 2019. High-resolution climate projections for South Asia to inform climate impacts and adaptation studies in the Ganges-BrahmaputraMeghna and Mahanadi deltas. Sci. Total Environ. 650, 1499-1520. https://doi.org/10.1016/j.scitotenv.2018.08.376

Jarritt, N.P., Lawrence, D.S.L., 2006. Simulating Fine Sediment Delivery in Lowland Catchments: Model Development and Application of INCA-Sed, in: Owens, P.N., Collins, A.J. (Eds.), Soil Erosion and Sediment Redistribution in River Catchments: Measurement, Modelling and Management. CAB International, pp. 207-2016.

Kazama, S., Hagiwara, T., Ranjan, P., Sawamoto, M., 2007. Evaluation of groundwater resources in wide inundation areas of the Mekong River basin. J. Hydrol. 340, 233-243. https://doi.org/10.1016/j.jhydrol.2007.04.017

Kondolf, G.M., 1997. PROFILE: Hungry Water: Effects of Dams and Gravel Mining on River Channels. Environ. Manage. 21, 533-551. https://doi.org/10.1007/s002679900048

Kondolf, G.M., Rubin, Z.K., Minear, J.T., 2014. Dams on the Mekong: Cumulative sediment starvation. Water Resour. Res. 50, 5158-5169. https://doi.org/10.1002/2013WR014651

Kondolf, G.M., Schmitt, R.J.P., Carling, P., Darby, S.E., Arias, M., Bizzi, S., Castelletti, A., Cochrane, T.A., Gibson, S., Kummu, M., Oeurng, C., Rubin, Z., Wild, T., 2018. Changing sediment budget of the Mekong: Cumulative threats and management strategies for a large river basin. Sci. Total Environ. 625, 114-134. https://doi.org/10.1016/j.scitotenv.2017.11.361

Kummu, M., Lu, X.X., Wang, J.J., Varis, O., 2010. Basin-wide sediment trapping efficiency of emerging reservoirs along the Mekong. Geomorphology 119, 181-197. https://doi.org/10.1016/j.geomorph.2010.03.018 
573

574

575

576

577

578

579

580

581

582

583

584

585

586

587

588

589

590

591

592

593

594

595

596

597

598

599

600

601

602

603

604

605

606

607

608

609

610

Kummu, M., Varis, O., 2007. Sediment-related impacts due to upstream reservoir trapping, the Lower Mekong River. Geomorphology 85, 275-293. https://doi.org/10.1016/j.geomorph.2006.03.024

Lafon, T., Dadson, S.J., Buys, G., Prudhomme, C., 2013. Bias correction of daily precipitation simulated by a regional climate model: a comparison of methods. Int. J. Climatol. 33, 1367-1381. https://doi.org/10.1002/joc.3518

Lázár, A.N., Butterfield, D., Futter, M.N., Rankinen, K., Thouvenot-Korppoo, M., Jarritt, N.P., Lawrence, D.S.L., Wade, A.J., Whitehead, P.G., 2010. An assessment of the fine sediment dynamics in an upland river system: INCA-Sed modifications and implications for fisheries. Sci. Total Environ. 408, 2555-2566. https://doi.org/10.1016/j.scitotenv.2010.02.030

Li, T., Wang, S., Liu, Y., Fu, B., Zhao, W., 2018. Driving forces and their contribution to the recent decrease in sediment flux to ocean of major rivers in China. Sci. Total Environ. 634, 534-541. https://doi.org/10.1016/j.scitotenv.2018.04.007

Lu, Q., Futter, M.N., Nizzetto, L., Bussi, G., Jürgens, M.D., Whitehead, P.G., 2016. Fate and Transport of Polychlorinated Biphenyls (PCBs) in the River Thames Catchment - Insights from a Coupled Multimedia Fate and Hydrobiogeochemical Transport Model. Sci. Total Environ. 572, 1461-1470. https://doi.org/10.1016/j.scitotenv.2016.03.029

Lu, Q., Whitehead, P.G., Bussi, G., Futter, M.N., Nizzetto, L., 2017. Modelling metaldehyde in catchments: a River Thames case-study. Environ. Sci. Process. Impacts 19, 586-595. https://doi.org/10.1039/C6EM00527F

Lu, X., Kummu, M., Oeurng, C., 2014. Reappraisal of sediment dynamics in the Lower Mekong River, Cambodia. Earth Surf. Process. Landforms 39, 1855-1865. https://doi.org/10.1002/esp.3573

Lu, X.X., Siew, R.Y., 2006. Water discharge and sediment flux changes over the past decades in the Lower Mekong River: possible impacts of the Chinese dams. Hydrol. Earth Syst. Sci. 10, 181-195. https://doi.org/10.5194/hess-10-181-2006

Mekong River Commission, 2010. IWRM-based Basin Development Strategy for the Lower Mekong Basin. Fourth draft. Mekong River Commission. MRC. 2010b. The Mekong Ricer Commission. (Available at: http://www.mrcmekong.org/. Accessed on 16/12/2010). United Nations Environment Programme. Afte.

Mekong River Commission, 2009. Initiative on sustainable hydropower work plan. Mekong River Commission.(Available at: http:// www.mrcmekong.org/programmes/hydropower/hydropower-pub.htm. Accessed on: 17/12/2010).

Meshkova, L. V., Carling, P.A., 2012. The geomorphological characteristics of the Mekong River in northern Cambodia: A mixed bedrock-alluvial multi-channel network. Geomorphology 147-148, 2-17. https://doi.org/10.1016/j.geomorph.2011.06.041 
Milliman, J.D., Meade, R.H., 1983. World-Wide Delivery of River Sediment to the Oceans. J. Geol. 91, 1-21. https://doi.org/10.1086/628741

Minderhoud, P.S.J., Coumou, L., Erkens, G., Middelkoop, H., Stouthamer, E., 2019. Mekong delta much lower than previously assumed in sea-level rise impact assessments. Nat. Commun. 10, 3847. https://doi.org/10.1038/s41467-019-11602-1

Nguyen, H.Q., Korbee, D., Ho, H.L., Weger, J., Thi Thanh Hoa, P., Thi Thanh Duyen, N., Dang Manh Hong Luan, P., Luu, T.T., Ho Phuong Thao, D., Thi Thu Trang, N., Hermans, L., Evers, J., Wyatt, A., Chau Nguyen, X.Q., Long Phi, H., 2019. Farmer adoptability for livelihood transformations in the Mekong Delta: a case in Ben Tre province. J. Environ. Plan. Manag. 62, 1603-1618. https://doi.org/10.1080/09640568.2019.1568768

Nie, J., Ruetenik, G., Gallagher, K., Hoke, G., Garzione, C.N., Wang, W., Stockli, D., Hu, X., Wang, Z., Wang, Y., Stevens, T., Danišík, M., Liu, S., 2018. Rapid incision of the Mekong River in the middle Miocene linked to monsoonal precipitation. Nat. Geosci. 11, 944-948. https://doi.org/10.1038/s41561-018-0244-z

Nizzetto, L., Bussi, G., Futter, M.N., Butterfield, D., Whitehead, P.G., 2016. A theoretical assessment of microplastic transport in river catchments and their retention by soils and river sediments. Environ. Sci. Process. Impacts 18, 1050-1059. https://doi.org/10.1039/C6EM00206D

Schmitt, R.J.P., Bizzi, S., Castelletti, A., Opperman, J.J., Kondolf, G.M., 2019. Planning dam portfolios for low sediment trapping shows limits for sustainable hydropower in the Mekong. Sci. Adv. 5, eaaw2175. https://doi.org/10.1126/sciadv.aaw2175

Syvitski, J.P.M., 2008. Deltas at risk. Sustain. Sci. 3, 23-32. https://doi.org/10.1007/s11625008-0043-3

Syvitski, J.P.M., Kettner, A.J., Overeem, I., Hutton, E.W.H., Hannon, M.T., Brakenridge, G.R., Day, J., Vörösmarty, C., Saito, Y., Giosan, L., Nicholls, R.J., 2009. Sinking deltas due to human activities. Nat. Geosci. 2, 681-686. https://doi.org/10.1038/ngeo629

Tessler, Z.D., Vörösmarty, C.J., Grossberg, M., Gladkova, I., Aizenman, H., 2016. A global empirical typology of anthropogenic drivers of environmental change in deltas. Sustain. Sci. 11, 525-537. https://doi.org/10.1007/s11625-016-0357-5

Tessler, Z.D., Vorosmarty, C.J., Grossberg, M., Gladkova, I., Aizenman, H., Syvitski, J.P.M., Foufoula-Georgiou, E., 2015. Profiling risk and sustainability in coastal deltas of the world. Science (80-. ). 349, 638-643. https://doi.org/10.1126/science.aab3574

Tessler, Z.D., Vörösmarty, C.J., Overeem, I., Syvitski, J.P.M., 2018. A model of water and sediment balance as determinants of relative sea level rise in contemporary and future deltas. Geomorphology 305, 209-220. https://doi.org/10.1016/j.geomorph.2017.09.040

Thuc, T., Van Thang, N., Thi Lan Huong, H., Van Khiem, M., Xuan Hien, N., Ha Phong, D., 2016. Climate Change and Sea Level Rise Scenarios for Viet Nam: A Summary for 
policymakers, Report to Vietnam Ministry of Natural Resources and Environment.

Van, T.P.D., Carling, P.A., Atkinson, P.M., 2012. Modelling the bulk flow of a bedrockconstrained, multi-channel reach of the Mekong River, Siphandone, southern Laos. Earth Surf. Process. Landforms 37, 533-545. https://doi.org/10.1002/esp.2270

Vörösmarty, C.J., Meybeck, M., Fekete, B., Sharma, K., Green, P., Syvitski, J.P.M., 2003. Anthropogenic sediment retention: major global impact from registered river impoundments. Glob. Planet. Change 39, 169-190. https://doi.org/10.1016/S09218181(03)00023-7

Wade, A.J., Durand, P., Beaujouan, V., Wessel, W.., Raat, K.J., Whitehead, P.G., Butterfield, D., Rankinen, K., Lepisto, A., 2002. A nitrogen model for European catchments: INCA, new model structure and equations. Hydrol. Earth Syst. Sci. 6, 559-582. https://doi.org/10.5194/hess-6-559-2002

Walling, D.E., 2008. The Changing Sediment Load of the Mekong River. AMBIO A J. Hum. Environ. $\quad 37, \quad 150-157 . \quad \mathrm{https} / / / \mathrm{doi} .0 \mathrm{~g} / 10.1579 / 0044-$ 7447(2008)37[150:TCSLOT]2.0.CO;2

Walling, D.E., Fang, D., 2003. Recent trends in the suspended sediment loads of the world's rivers. Glob. Planet. Change 39, 111-126. https://doi.org/10.1016/S0921-8181(03)000201

Wang, W., Lu, H., Ruby Leung, L., Li, H.-Y., Zhao, J., Tian, F., Yang, K., Sothea, K., 2017. Dam Construction in Lancang-Mekong River Basin Could Mitigate Future Flood Risk From Warming-Induced Intensified Rainfall. Geophys. Res. Lett. 44, 10,378-10,386. https://doi.org/10.1002/2017GL075037

Whitehead, P.G., Barbour, E., Futter, M.N., Sarkar, S., Rodda, H., Caesar, J., Butterfield, D., Jin, L., Sinha, R., Nicholls, R., Salehin, M., 2015. Impacts of climate change and socioeconomic scenarios on flow and water quality of the Ganges, Brahmaputra and Meghna (GBM) river systems: low flow and flood statistics. Environ. Sci. Process. Impacts 17, 1057-1069. https://doi.org/10.1039/c4em00619d

Whitehead, P.G., Jin, L., Bussi, G., Voepel, H.E., Darby, S.E., Vasilopoulos, G., Manley, R., Rodda, H., Hutton, C., Hackney, C., Tri, V.P.D., Hung, N.N., 2019. Water quality modelling of the Mekong River basin: Climate change and socioeconomics drive flow and nutrient flux changes to the Mekong Delta. Sci. Total Environ. 673, 218-229. https://doi.org/10.1016/j.scitotenv.2019.03.315

Whitehead, P.G., Wilson, E., Butterfield, D., Seed, K., 1998. A semi-distributed integrated flow and nitrogen model for multiple source assessment in catchments (INCA): Part II application to large river basins in south Wales and eastern England. Sci. Total Environ. 210-211, 559-583. https://doi.org/10.1016/S0048-9697(98)00038-2

Whitehead, P.G.G., Leckie, H., Rankinen, K., Butterfield, D., Futter, M.N.N., Bussi, G., 2016. An INCA model for pathogens in rivers and catchments: Model structure, sensitivity 
690

691

692

\section{2}

analysis and application to the River Thames catchment, UK. Sci. Total Environ. 572, 1601-1610. https://doi.org/10.1016/j.scitotenv.2016.01.128

Zarfl, C., Lumsdon, A.E., Berlekamp, J., Tydecks, L., Tockner, K., 2015. A global boom in hydropower dam construction. Aquat. Sci. 77, 161-170. https://doi.org/10.1007/s00027014-0377-0 


\section{Supplementary material}

2 Table S6. River reaches/sub-catchments and corresponding characteristics.

\begin{tabular}{|c|c|c|c|c|c|c|c|c|c|c|c|c|c|}
\hline $\begin{array}{l}\text { INCA } \\
\text { ID }\end{array}$ & Name & River & $\begin{array}{c}\text { Sub- } \\
\text { catchment } \\
\text { area }\left(\mathbf{k m}^{2}\right)\end{array}$ & $\begin{array}{l}\text { Length } \\
\text { (m) }\end{array}$ & $\begin{array}{l}\text { Stream } \\
\text { gauge? }\end{array}$ & $\begin{array}{c}\text { Lon } \\
\text { (downstream } \\
\text { section) }\end{array}$ & $\begin{array}{c}\text { Lat } \\
\text { (downstream } \\
\text { section) }\end{array}$ & $\begin{array}{c}\% \\
\text { arable }\end{array}$ & $\begin{array}{c}\% \\
\text { grassland }\end{array}$ & $\begin{array}{c}\% \\
\text { forest }\end{array}$ & $\begin{array}{c}\% \\
\text { water }\end{array}$ & $\begin{array}{c}\% \\
\text { urban }\end{array}$ & $\begin{array}{c}\% \\
\text { bare }\end{array}$ \\
\hline 1 & Gushui & Mekong & 78476 & 500000 & NO & 98.751606 & 28.609973 & 38.51 & 61.19 & 0.01 & 0.04 & 0.00 & 0.25 \\
\hline 2 & Manwan & Mekong & 34449 & 661830 & NO & 100.498386 & 24.523349 & 42.14 & 40.22 & 9.62 & 0.05 & 0.00 & 7.97 \\
\hline 3 & Ban Mau & Mekong & 49004 & 508289 & NO & 101.154146 & 21.523381 & 27.92 & 27.42 & 42.83 & 0.87 & 0.14 & 0.82 \\
\hline 4 & Pak Beng & Mekong & 49401 & 437269 & NO & 101.031725 & 19.850000 & 14.03 & 42.18 & 43.63 & 0.07 & 0.09 & 0.00 \\
\hline 5 & $\begin{array}{c}\text { Luang } \\
\text { Prabang }\end{array}$ & Mekong & 6876 & 154609 & NO & 102.201713 & 20.059143 & 17.29 & 45.19 & 37.22 & 0.30 & 0.00 & 0.00 \\
\hline 6 & $\begin{array}{c}\text { Luang } \\
\text { Prabang } \\
\text { Gauge }\end{array}$ & Mekong & 27583 & 81276 & $\begin{array}{l}\text { Luang } \\
\text { Prabang }\end{array}$ & 102.130787 & 19.894177 & 4.42 & 61.51 & 33.77 & 0.30 & 0.00 & 0.00 \\
\hline 7 & Xayabouri & Mekong & 2362 & 106607 & NO & 101.819190 & 19.244089 & 1.71 & 57.53 & 40.67 & 0.09 & 0.00 & 0.00 \\
\hline 8 & Pak Lay & Mekong & 10109 & 124909 & NO & 101.530148 & 18.326022 & 6.51 & 57.25 & 35.62 & 0.62 & 0.00 & 0.00 \\
\hline 9 & Sanakham & Mekong & 6876 & 87866 & NO & 101.560847 & 17.837641 & 3.64 & 53.58 & 42.49 & 0.29 & 0.00 & 0.00 \\
\hline 10 & $\begin{array}{l}\text { Santhong- } \\
\text { Pakchom }\end{array}$ & Mekong & 7051 & 85882 & NO & 102.049941 & 18.199854 & 25.93 & 43.05 & 30.38 & 0.64 & 0.00 & 0.00 \\
\hline 11 & Mukdahan & Mekong & 66502 & 766312 & Mukdahan & 104.743392 & 16.539898 & 50.76 & 21.94 & 26.82 & 0.48 & 0.00 & 0.00 \\
\hline 12 & Ban Kum & Mekong & 10901 & 207313 & NO & 105.585762 & 15.415940 & 49.72 & 22.59 & 26.16 & 1.51 & 0.02 & 0.00 \\
\hline 13 & Latsua & Mekong & 605 & 41526 & NO & 105.584129 & 15.329925 & 59.48 & 19.83 & 19.08 & 1.60 & 0.01 & 0.00 \\
\hline 14 & Pakse & Mekong & 8111 & 37282 & Pakse & 105.800065 & 15.113341 & 49.94 & 23.02 & 24.23 & 2.81 & 0.00 & 0.00 \\
\hline 15 & $\begin{array}{l}\text { Stung } \\
\text { Treng }\end{array}$ & Mekong & 11056 & 205656 & NO & 105.983147 & 13.569074 & 32.11 & 36.35 & 30.75 & 0.79 & 0.00 & 0.00 \\
\hline 16 & $\begin{array}{l}\text { Stung } \\
\text { Treng } \\
\text { Gauge } \\
\end{array}$ & Mekong & 12911 & 463660 & $\begin{array}{l}\text { Stung } \\
\text { Treng }\end{array}$ & 105.940913 & 13.521594 & 18.78 & 42.08 & 36.06 & 3.08 & 0.00 & 0.00 \\
\hline 17 & $\begin{array}{l}\text { Sambor- } \\
\text { Kratie }\end{array}$ & Mekong & 3437 & 96815 & Kratie & 105.949996 & 12.780950 & 8.04 & 41.14 & 49.57 & 1.25 & 0.00 & 0.00 \\
\hline 18 & $\begin{array}{l}\text { Phnom } \\
\text { Penh }\end{array}$ & Mekong & 109790 & 252222 & NO & 104.957539 & 11.560835 & 6.55 & 33.71 & 54.93 & 4.81 & 0.00 & 0.00 \\
\hline 19 & $\begin{array}{l}\text { River } \\
\text { mouth }\end{array}$ & Mekong & 23566 & 307320 & NO & 106.198292 & 9.533241 & 44.11 & 24.26 & 28.43 & 3.19 & 0.00 & 0.01 \\
\hline 20 & Nam Loi & Nam Loi & 15274 & 351567 & NO & 100.722575 & 21.310804 & 77.66 & 10.15 & 8.49 & 3.60 & 0.00 & 0.10 \\
\hline 21 & $\begin{array}{c}\text { Nam } \\
\text { Suong }\end{array}$ & $\begin{array}{c}\text { Nam } \\
\text { Suong }\end{array}$ & 5723 & 145064 & NO & 102.328473 & 20.051469 & 11.17 & 50.71 & 38.10 & 0.01 & 0.01 & 0.00 \\
\hline 22 & Nam Khan & $\begin{array}{l}\text { Nam } \\
\text { Khan }\end{array}$ & 6942 & 188836 & NO & 102.222610 & 19.747571 & 0.03 & 62.05 & 37.92 & 0.00 & 0.00 & 0.00 \\
\hline 23 & $\begin{array}{l}\text { Nam } \\
\text { Ngum }\end{array}$ & $\begin{array}{l}\text { Nam } \\
\text { Ngum }\end{array}$ & 8311 & 214685 & NO & 102.547535 & 18.529925 & 0.14 & 57.62 & 42.24 & 0.00 & 0.00 & 0.00 \\
\hline 24 & $\begin{array}{l}\text { Nam } \\
\text { Nhiep }\end{array}$ & $\begin{array}{l}\text { Nam } \\
\text { Nhiep }\end{array}$ & 3757 & 152219 & NO & 103.552026 & 18.645862 & 6.94 & 54.14 & 33.65 & 5.27 & 0.00 & 0.00 \\
\hline 25 & $\begin{array}{c}\text { Nam } \\
\text { Cadinh }\end{array}$ & $\begin{array}{c}\text { Nam } \\
\text { Cadinh }\end{array}$ & 13959 & 247069 & NO & 104.147564 & 18.355858 & 2.73 & 56.38 & 40.89 & 0.00 & 0.00 & 0.00 \\
\hline 26 & $\begin{array}{l}\text { Se Bang } \\
\text { Hieng }\end{array}$ & $\begin{array}{c}\text { Se Bang } \\
\text { Hieng }\end{array}$ & 19959 & 297457 & NO & 105.245797 & 16.050037 & 1.02 & 25.94 & 73.00 & 0.04 & 0.00 & 0.00 \\
\hline 27 & Nam Mun & $\begin{array}{l}\text { Nam } \\
\text { Mun }\end{array}$ & 119289 & 618058 & NO & 105.455882 & 15.269046 & 26.96 & 31.06 & 41.68 & 0.30 & 0.00 & 0.00 \\
\hline 28 & Se Kong & Se Kong & 23385 & 371984 & NO & 106.332559 & 14.430805 & 86.06 & 6.06 & 6.74 & 1.11 & 0.03 & 0.00 \\
\hline 29 & Se San & Se San & 15434 & 304239 & NO & 106.936557 & 14.039971 & 4.26 & 31.64 & 63.78 & 0.32 & 0.00 & 0.00 \\
\hline 30 & Sre Pok & Sre Pok & 27212 & 340412 & NO & 107.037454 & 13.393443 & 12.24 & 37.69 & 49.42 & 0.65 & 0.00 & 0.00 \\
\hline
\end{tabular}




\section{Discussion on the aggregated reservoir trap efficiency assumption}

7 One of the assumptions of this study is that the impact of multiple reservoirs lying within a single sub8 catchment on the sediment transport can be approximated to the impact of a "virtual" reservoir located at the sub-catchment outlet (i.e., where the most downstream dam is located), whose capacity is equal to the sum of the capacity of all the dams within the sub-catchment. The main advantage of this assumption is that the model structure can be kept relatively small, so to allow running a Monte Carlo-like model calibration and a set of future climate projections in a reasonable amount of time.

While this assumption obviously carries a simplification, due to the fact that the global impact of a system of dams will also depend on their corresponding locations, the characteristics of the subcatchments they drain and their sizes, we provide in this section a discussion of why this simplification is reasonable for the scale and scope of the present study.

A simple modelling exercise was set up, using the Se Kong River as a case study. The Se Kong river is a major tributary of the Mekong River. Its upper course is located almost entirely in southern Lao and its confluence with the Mekong River is located near Stung Treng, in eastern Cambodia. Figure S7 shows the catchment extension and the river course.

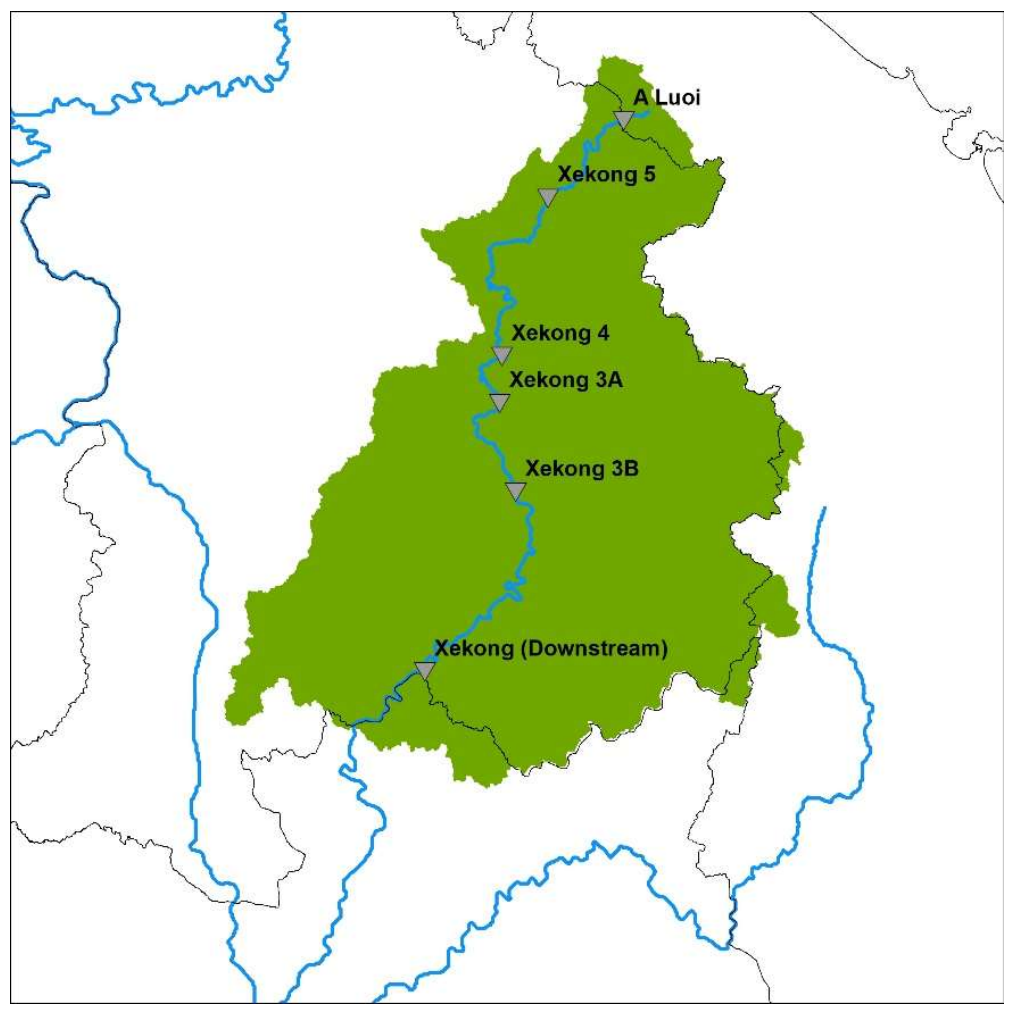

Figure S7. Se Kong River catchment and dams on its main stem.

Several dams exist on its course: A Luoi, Xekong 5, Xekong 4, Xekong 3A, Xekong 3B and Xekong (total reservoir capacity: $1,181 \mathrm{Mm}^{3}$ ). The characteristics of the dams are shown in Figure S7.

Table S7. Main characteristics of the dams on the Se Kong River.

\begin{tabular}{|c|c|c|c|}
\hline Dam name & Catchment area $\left(\mathbf{k m}^{2}\right)$ & Storage capacity $\left(\mathbf{M m}^{3}\right)$ & Trap efficiency (Brune, 1953) \\
\hline A Luoi & 399 & 170 & 96 \\
\hline Xekong 5 & 2555 & 330 & 91 \\
\hline
\end{tabular}




\begin{tabular}{|c|c|c|c|}
\hline Xekong 4 & 5176 & 400 & 87 \\
\hline Xekong 3A & 5883 & 105 & 64 \\
\hline Xekong 3B & 8648 & 100 & 54 \\
\hline Xekong & 18645 & 76 & 28 \\
\hline
\end{tabular}

Two INCA model set-ups were implemented on the Se Kong River:

1. The catchment modelled as a single, lumped INCA catchment;

2. The catchment modelled as a set of 6 INCA sub-catchment.

The model parameters used in this implementation were the same parameters calibrated as shown in the paper. The effect of the dams was computed in the same way, i.e., by adjusting the sediment transport capacity to reproduce the trap efficiency computed according to Brune (1953). In the first set-up ("Lumped"), the trap efficiency of a single, "virtual" dam was computed based on the sum of the reservoir capacity of all the six reservoirs. In the second set-up ("Disaggregated"), the trap efficiency of each dam was computed based on its reservoir capacity. The model was then run for the time period 1980-2009. The model results in terms of suspended sediment flux at the catchment outlet are shown in Figure S8. It can be noticed that the two implementations obtain reasonably similar results, with only minor differences.

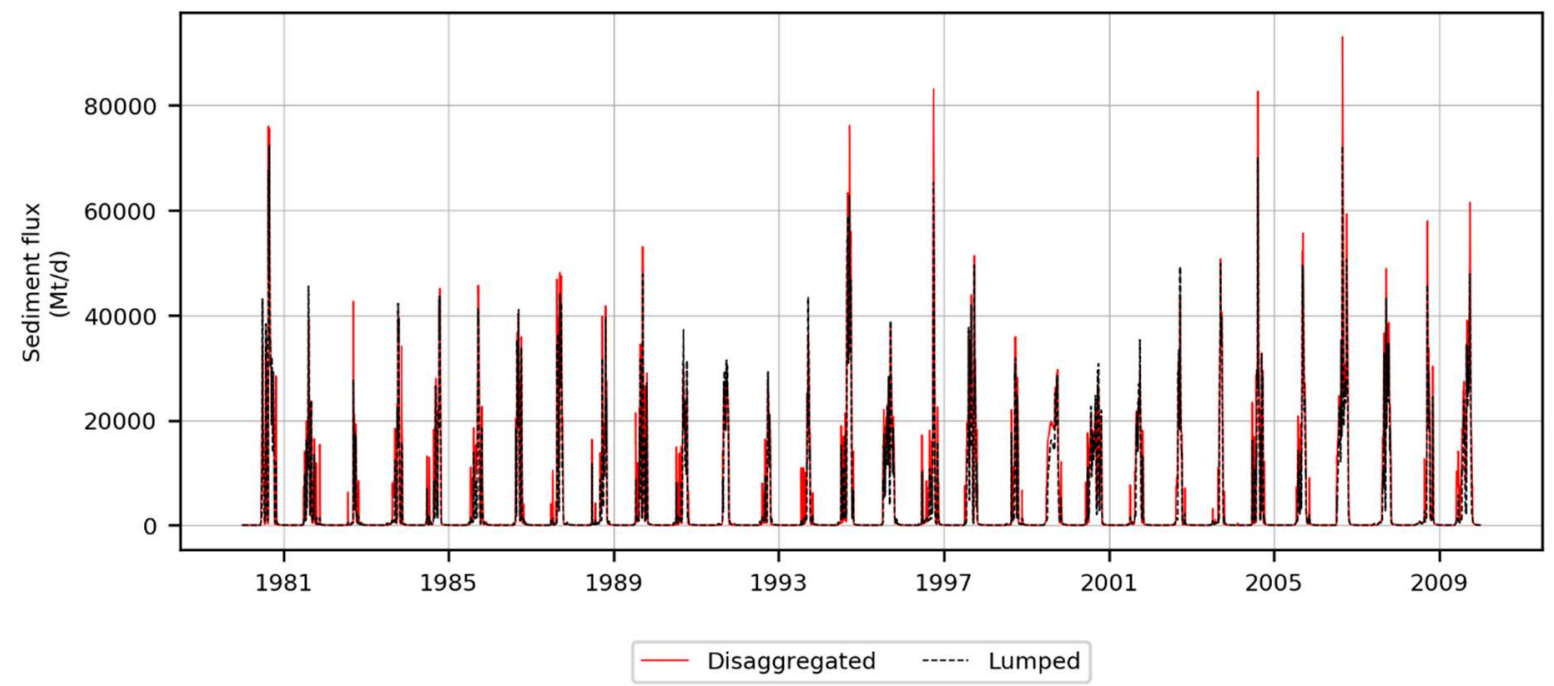

Figure S8. INCA model results (daily suspended sediment flux) for the "lumped" and the "Disaggregated" model set-ups of the Se Kong River.

This outcome shows that the error introduced by this assumption is likely to be much smaller than the other sources of modelling errors (errors in the input data, INCA model errors, climate projection errors). Furthermore, this assumption was only applied to the tributaries of the River Mekong, which account for $18 \%$ only of the total reservoir storage capacity of the Mekong catchment (being the Se Kong River storage capacity around half of all the tributary storage capacity), and therefore its potential impact is limited. While we acknowledge that a more detailed and comprehensive model could certainly be beneficial for the reduction of the errors, we believe that the relative contribution of this assumption to the global model error is reasonably low. 